\title{
The net carbon footprint of a newly created boreal hydroelectric reservoir
}

\author{
Cristian R. Teodoru, ${ }^{1,2}$ Julie Bastien, ${ }^{3}$ Marie-Claude Bonneville, ${ }^{4}$ Paul A. del Giorgio, ${ }^{1}$ \\ Maud Demarty, ${ }^{3}$ Michelle Garneau, ${ }^{5}$ Jean-Francois Hélie, ${ }^{5}$ Luc Pelletier, ${ }^{4,5}$ Yves T. Prairie, ${ }^{1}$ \\ Nigel T. Roulet, ${ }^{6,7}$ Ian B. Strachan, ${ }^{4}$ and Alain Tremblay ${ }^{8}$ \\ Received 19 August 2011; revised 30 January 2012; accepted 19 March 2012; published 17 May 2012.
}

[1] We present here the first comprehensive assessment of the carbon (C) footprint associated with the creation of a boreal hydroelectric reservoir (Eastmain-1 in northern Québec, Canada). This is the result of a large-scale, interdisciplinary study that spanned over a 7-years period (2003-2009), where we quantified the major $\mathrm{C}$ gas $\left(\mathrm{CO}_{2}\right.$ and $\left.\mathrm{CH}_{4}\right)$ sources and sinks of the terrestrial and aquatic components of the pre-flood landscape, and also for the reservoir following the impoundment in 2006. The pre-flood landscape was roughly neutral in terms of $\mathrm{C}$, and the balance between pre- and post-flood $\mathrm{C}$ sources/sinks indicates that the reservoir was initially (first year post-flood in 2006) a large net source of $\mathrm{CO}_{2}\left(2270 \mathrm{mg} \mathrm{C} \mathrm{m}^{-2} \mathrm{~d}^{-1}\right)$ but a much smaller source of $\mathrm{CH}_{4}\left(0.2 \mathrm{mg} \mathrm{C} \mathrm{m}^{-2} \mathrm{~d}^{-1}\right)$. While net $\mathrm{CO}_{2}$ emissions declined steeply in subsequent years (down to $835 \mathrm{mg} \mathrm{C} \mathrm{m}^{-2} \mathrm{~d}^{-1}$ in 2009), net $\mathrm{CH}_{4}$ emissions remained constant or increased slightly relative to pre-flood emissions. Our results also suggest that the reservoir will continue to emit carbon gas over the long-term at rates exceeding the carbon footprint of the pre-flood landscape, although the sources of $\mathrm{C}$ supporting these emissions have yet to be determined. Extrapolation of these empirical trends over the projected life span (100 years) of the reservoir yields integrated long-term net $\mathrm{C}$ emissions per energy generation well below the range of the natural-gas combined-cycle, which is considered the current industry standard.

Citation: Teodoru, C. R., et al. (2012), The net carbon footprint of a newly created boreal hydroelectric reservoir, Global Biogeochem. Cycles, 26, GB2016, doi:10.1029/2011GB004187.

\section{Introduction}

[2] There are currently more than 45,000 large dams constructed worldwide with the purpose of power generation, agricultural and domestic use, and their number continue to increase globally at a fast pace [World Commission on Dams,

\footnotetext{
${ }^{1}$ Groupe de Recherche Interuniversitaire en Limnologie, Department of Biological Sciences, University of Québec at Montréal, Montreal, Quebec, Canada.

${ }^{2}$ Now at Department of Earth and Environmental Science, Katholieke Universiteit Leuven, Leuven, Belgium.

${ }^{3}$ Environnement Illimité Inc, Montreal, Quebec, Canada.

${ }^{4}$ Department of Natural Resource Sciences, McGill University, Ste. Anne de Bellevue, Quebec, Canada.

${ }^{5}$ Centre de Recherche en Géochimie Isotopique et en Géochronologie, Department of Geography, University of Québec at Montréal, Montreal, Quebec, Canada.

${ }^{6}$ Department of Geography, McGill University, Montreal, Quebec, Canada.

${ }^{7}$ Global Environment and Climate Change Centre, McGill University, Montreal, Quebec, Canada.

${ }^{8}$ Hydro-Québec, Montreal, Quebec, Canada.

Corresponding author: C. R Teodoru, Department of Earth and Environmental Science, Katholieke Universiteit Leuven, Celestijnenlaan 200E, Box 2411, B-3001 Leuven, Belgium. (teo.teodoru@ees.kuleuven.be)

Copyright 2012 by the American Geophysical Union. 0886-6236/12/2011GB004187
}

2000; Downing et al., 2006]. Among the multiple environmental, ecological, biogeochemical and social impacts associated with reservoir development [Rosenberg et al., 1995, 1997; Vörösmarty et al., 1997; Friedl and Wüest, 2002], the emission of carbon (C) gases is steadily becoming a focus of both scientific and economic concerns. Hydroelectric production was until quite recently, considered for all practical purposes as relatively C-neutral with close to zero-emission [Hoffert et al., 1998; Victor, 1998], but there is mounting evidence that hydroelectric reservoirs may in fact emit significant amounts of both carbon dioxide $\left(\mathrm{CO}_{2}\right)$ and methane $\left(\mathrm{CH}_{4}\right)$. Over the last decade, there have been increasing efforts to understand the complex interplay between biogeochemical and physical processes responsible for elevated levels of $\mathrm{CO}_{2}$ and $\mathrm{CH}_{4}$ emission that have been recorded following reservoir creation. Emissions of $\mathrm{CO}_{2}$ and $\mathrm{CH}_{4}$ vary greatly within and among reservoirs depending on geographic location, climate, morphometry and age of impoundments, watershed properties, and management practices [St. Louis et al., 2000; dos Santos et al., 2004; Barros et al., 2011] making it difficult, if not impossible, to extrapolate observations from one reservoir to another.

[3] The magnitude of global $\mathrm{C}$ emissions from reservoirs has been a longstanding debate, in part due to the scarcity of robust quantitative estimates, a lack of common methodologies for measurements, and the lack of process based 
models to extend the observational data based beyond reservoirs where measurements have been made [Rosa and Schaeffer, 1994, 1995; Fearnside, 1996; St. Louis et al., 2000; Giles, 2006]. A recent meta-analysis of published data from reservoirs with a worldwide distribution suggests globally, hydroelectric reservoir emit in the range of $48 \mathrm{Tg} \mathrm{C}$ $\mathrm{CO}_{2} \mathrm{y}^{-1}$, and $3 \mathrm{Tg} \mathrm{C}-\mathrm{CH}_{4} \mathrm{y}^{-1}$ [Barros et al., 2011], substantially less than previous reports [St. Louis et al. 2000], mostly due to differences in the estimate of global reservoir surface. Although still substantial, these estimates are entirely based on the emissions measured at the surface and do not take into account the $\mathrm{C}$ sinks and sources of the natural ecosystems that were flooded. Thus, the current data do not allow effective assessments of the true impact of reservoirs in regional or global $\mathrm{C}$ budgets, or to place hydroelectricity production in the context of net emissions due to the actual reservoir construction and operation, over and above the natural regional fluxes.

[4] A realistic assessment of the actual $\mathrm{C}$ footprint of hydroelectric reservoirs, and thus of $\mathrm{C}$ emissions associated with hydroelectric energy generation requires, in addition to reliable estimates of reservoir $\mathrm{CO}_{2}$ and $\mathrm{CH}_{4}$ emissions taken over space and time, robust estimates of the $\mathrm{C}$ sinks and sources from the terrestrial and natural aquatic ecosystems that existed in the pre-flood landscape and which are lost due to flooding [St. Louis et al., 2000; Teodoru et al., 2011]. In spite of the increasing awareness of the significance of reservoir $\mathrm{C}$ emissions, to our knowledge no such pre-, post flooding $\mathrm{C}$ balance has ever been carried out.

[5] The overall aim of our study was to: 1) determine the complete pre-flood $\mathrm{C}$ sink/source balance of the reservoir basin; 2) determine the post-flood $\mathrm{C}$ balance including an estimate of spatial and temporal variability in $\mathrm{CO}_{2}$ and $\mathrm{CH}_{4}$ emissions from the reservoir; and finally, 3) combine these two estimates to calculate the net $\mathrm{C}$ footprint of a reservoir basin. The study focuses on the Eastmain-1 reservoir that was created in 2006 in the boreal region of Northwestern Québec. The research we present here represents a synthesis of a large cross-disciplinary collaborative project carried out by a team of scientists from several universities, consulting companies and industry (Hydro-Québec). Launched in 2003, and spanning a 7-year period, the project involved a combination of extensive empirical studies of the pre-flood ecosystems, detailed follow-up of the reservoir, and modeling of the landscape $C$ sink/source balance. During the initial phase of the project, from 2003 to 2005, the team monitored and quantified the $\mathrm{CO}_{2}$ and $\mathrm{CH}_{4}$ sources and sinks of the preflood landscape, including $\mathrm{C}$ storage and $\mathrm{CO}_{2}$ and $\mathrm{CH}_{4}$ emission in forests, peatlands, lakes, streams and rivers. The basin was flooded at the end of 2005, and over the next four years (2006 to 2009), we quantified C gas emissions from the reservoir, by integrating detailed spatial and temporal surveys of surface water $\mathrm{CO}_{2}$ and $\mathrm{CH}_{4}$ concentrations and fluxes. In addition to diffusive fluxes, we measured methane bubbling and degassing fluxes at the powerhouse. We also determined $\mathrm{C}$ sedimentation and net storage in the reservoir, and continued to monitor the net $\mathrm{C}$ exchange by the surrounding terrestrial landscape. The net $\mathrm{C}$ emissions due to the reservoir, for each of the first four years after flooding, were determined from the difference between the pre- and post-flood $\mathrm{C}$ sink/source budgets over the entire surface of the flooded landscape, and these initial net emissions were projected over the next decades and further validated with existing data from older reservoirs in the region. These results represent, to the best of our knowledge, the first comprehensive, pre- and post-flood net $\mathrm{C}$ balances ever carried out for a hydroelectric reservoir, and provide robust estimates of the net $\mathrm{C}$ footprint directly associated with hydroelectricity generation of a northern reservoir.

\section{Experimental Section}

\subsection{Study Site}

[6] The Eastmain-1 reservoir ( 51 to $52^{\circ} \mathrm{N}$ and 72 to $76^{\circ} \mathrm{W}$ ) lies within the James Bay lowland of boreal Québec, Canada (Figure 1 and see full description of the area in auxiliary material). ${ }^{1}$ The Eastmain River is one of the major boreal rivers in northern Québec. It originates in the North-Central Québec region, and flows west across $800 \mathrm{~km}$, draining a total area of about $46,400 \mathrm{~km}^{2}$ and discharging into James Bay. The Eastmain-1 reservoir is located about $200 \mathrm{~km}$ upstream of the river mouth. It has a surface area of $602.9 \mathrm{~km}^{2}$, an average depth of $11 \mathrm{~m}$, and a total storage capacity of $6.94 \mathrm{~km}^{3}$ (drawdown $9 \mathrm{~m}$, active storage $4.21 \mathrm{~km}^{3}$ ). The theoretical hydraulic residence time (HRT) of the reservoir at a rated design flow of $550 \mathrm{~m}^{3} \mathrm{~s}^{-1}$ is on average 145 days. With an installed capacity of $485 \mathrm{MW}$, this hydropower station generates an annual output of $2.7 \mathrm{TWh}$. The total energy output is however expected to increase with the completion of the second powerhouse (Eastmain-1A, 768 MW) anticipated by the end of 2012.

[7] Filling up of the reservoir at the end of 2005 flooded a heterogeneous landscape composed of a diversity of terrestrial, wetland and aquatic ecosystems: approximately $182 \mathrm{~km}^{2}$ of the pre-flood landscape consisted of mature forest (91\% coniferous and $9 \%$ deciduous), $114 \mathrm{~km}^{2}$ was burned forest (95\% 17-year-old burned and 5\% 2-year-old burned), $46 \mathrm{~km}^{2}$ was non-forest soil, and $111 \mathrm{~km}^{2}$ was wetlands (1\% fens, $77 \%$ bogs, and $22 \%$ swamps/marshes) (Table 1 ). Additionally, there were 827 lakes of widely varying sizes, totaling an area of $67 \mathrm{~km}^{2}$, there were $82 \mathrm{~km}^{2}$ of main riverbed, and more than 827 stream segments with a total surface of $1.3 \mathrm{~km}^{2}$ (Table 1).

\subsection{General Approach}

[8] Our approach was to quantify the major carbon sources and sinks of both the pre-flood and post-flood landscape, and derive the net impact of this land cover transformation as the difference between the two. The pre-flood landscape was divided into three major components: Terrestrial (which includes forests and non-forest soils), wetlands (which include fens, bogs, swamps/marshes) and aquatic systems (which include streams, rivers and lakes). We estimated C sink/ sources for each of these individual components. In the case of terrestrial and wetland components, the $\mathrm{C}$ source/sink was determined as the net flux of $\mathrm{CO}_{2}$ and $\mathrm{CH}_{4}$ to the atmosphere. Aquatic systems however function simultaneously as net source of $\mathrm{C}$ gas to the atmosphere and net $\mathrm{C}$ sink to the landscape through sedimentation and storage. The latter is only possible because lakes receive substantial inputs of $\mathrm{C}$ from the watershed as well, and thus, the net $\mathrm{C}$ source/sink

\footnotetext{
${ }^{1}$ Auxiliary materials are available in the HTML. doi:10.1029/ 2011 GB004187.
} 


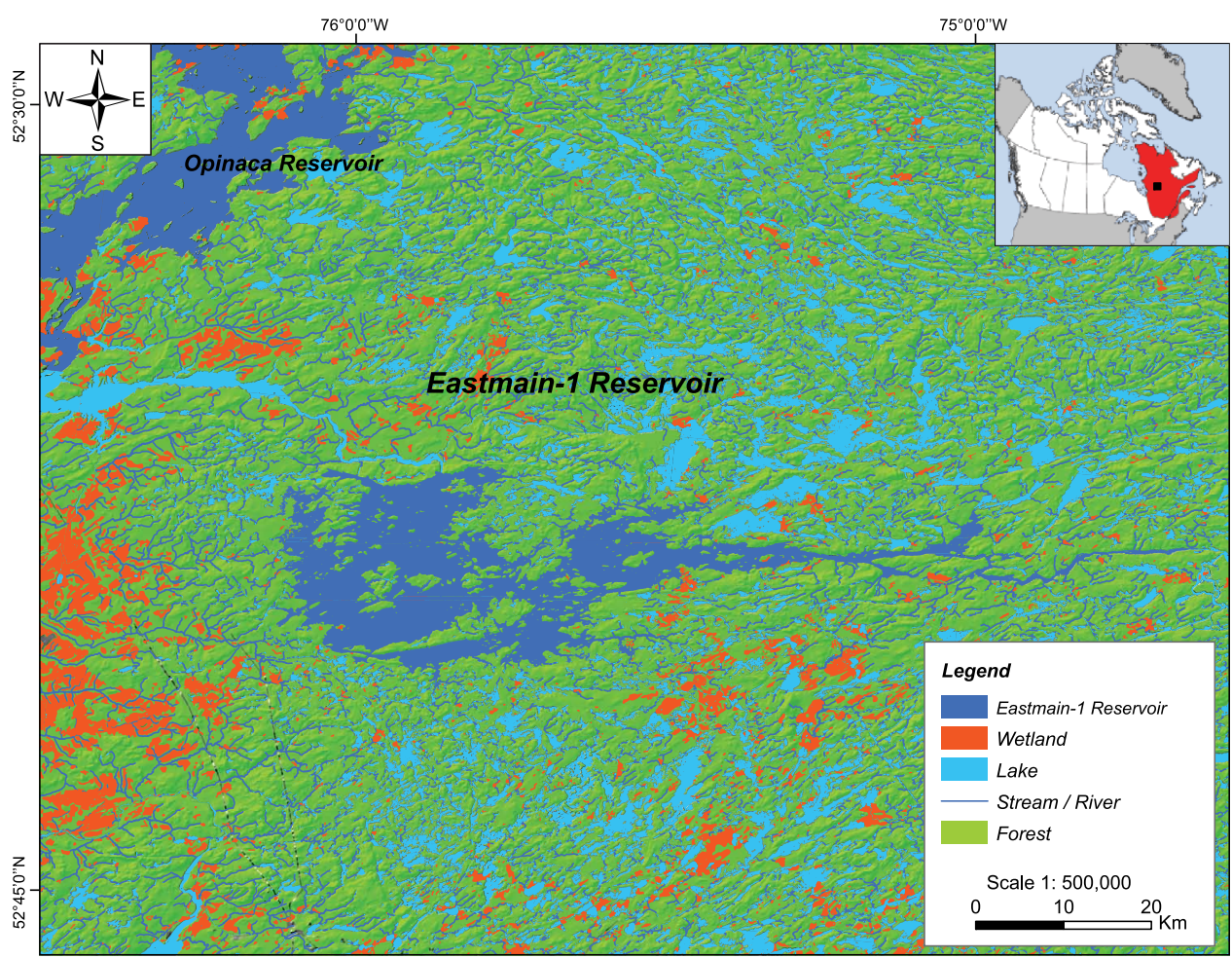

Figure 1. Map of the study area indicating the location of the reservoir and the distribution of terrestrial (forest and wetland) and natural aquatic ecosystem in the region.

balance of lakes cannot be derived only from net gas exchange but is instead determined as the difference between $\mathrm{CO}_{2}$ and $\mathrm{CH}_{4}$ emissions to the atmosphere and the rate of $\mathrm{C}$ burial in the sediment. As previous studies in boreal regions suggest that $\mathrm{CH}_{4}$ release during forest fire is negligible relative to $\mathrm{CO}_{2}$ representing only between 0.3 to $0.4 \%$ of the $\mathrm{CO}_{2}$ flux [Kasischke and Bruhwiler, 2002], fire $\mathrm{CH}_{4}$ flux was not included in the overall computation and the pre-flood balance was thus calculated as:

[9] Pre-flood $\mathrm{C}$ sink/source balance $=\left(\mathrm{Net}\right.$ terrestrial $\mathrm{CO}_{2}$ and $\mathrm{CH}_{4}$ exchange + fire $\mathrm{CO}_{2}$ flux $)+\left(\right.$ Net wetland $\mathrm{CO}_{2}$ and
$\mathrm{CH}_{4}$ exchange $)+\left(\right.$ Aquatic $\mathrm{CO}_{2}$ and $\mathrm{CH}_{4}$ emissions - lake sediment $\mathrm{C}$ burial).

[10] We followed the same general approach for the postflood landscape. The net post-flood C source/sink balance was thus calculated as:

[11] Reservoir $\mathrm{C}$ sink/source balance $=\mathrm{CO}_{2}$ exchange (diffusive + turbine) $+\mathrm{CH}_{4}$ exchange (diffusive + bubbling + turbine) - net $\mathrm{C}$ sedimentation.

[12] The degrading soils contained within the reservoir constitute an additional unquantified source of carbon to the system, a portion of which can ultimately be the source of the

Table 1. Weighted-Average and Range Variability of Diffusive Fluxes and C Storage in Natural Aquatic and Terrestrial Ecosystems Prior to Flooding ${ }^{\mathrm{a}}$

\begin{tabular}{|c|c|c|c|c|c|}
\hline \multicolumn{2}{|l|}{ Ecosystem } & \multirow{2}{*}{$\begin{array}{l}\text { Area } \\
\left(\mathrm{km}^{2}\right)\end{array}$} & \multicolumn{2}{|c|}{ Diffusive Flux (mg C m $\left.{ }^{-2} \mathrm{~d}^{-1}\right)$} & \multirow{2}{*}{$\begin{array}{c}\text { C Storage } \\
\left(\mathrm{mg} \mathrm{C} \mathrm{m}^{-2} \mathrm{~d}^{-1}\right)\end{array}$} \\
\hline Class & Subclass & & $\mathrm{CO}_{2}$ & $\mathrm{CH}_{4}$ & \\
\hline \multirow[t]{3}{*}{ Natural aquatic } & river & 82.0 & $398(279 / 445)$ & $1.0(0.8 / 1.1)$ & ND \\
\hline & lake & 66.9 & $239(229 / 247)$ & $2.8(0.9 / 4.2)$ & $-27(-10 /-52)$ \\
\hline & stream & 1.3 & $2751(1115 / 6019)$ & ND & ND \\
\hline Total aquatic & & 150.2 & $335(241 / 399)$ & $1.8(0.9 / 2.5)$ & $-27(-10 /-52)$ \\
\hline \multirow[t]{3}{*}{ Forest } & coniferous & 166.6 & $-159(-376 /-1)$ & $-0.24(-0.31 /-0.17)$ & ND \\
\hline & deciduous & 15.6 & $-471(-729 /-214)$ & $-0.08(-0.09 /-0.07)$ & ND \\
\hline & burned & 113.8 & $-9(-88 / 71)$ & $-0.24(-0.30 /-0.18)$ & ND \\
\hline Total forest & & 296.0 & $-117(-250 / 15)$ & $-0.22(-0.29 /-0.17)$ & ND \\
\hline Non-forest soil & & 45.9 & ND & ND & ND \\
\hline \multirow[t]{3}{*}{ Wetland } & peatland: fen & 1.1 & $1278(954 / 1603)$ & $35(30 / 40.5)$ & ND \\
\hline & peatland: bog & 85.4 & $-120(-233 /-6)$ & $39(33 / 45.5)$ & ND \\
\hline & swamp/marsh & 24.4 & $-102(-218 / 14)$ & $39(33 / 45.5)$ & ND \\
\hline Total wetland & & 110.9 & $-102(-218 / 14)$ & $39.3(33.1 / 45.5)$ & ND \\
\hline Total terrestrial (including non-forest soil) & & 452.8 & $-102(-217 / 14)$ & $9.5(7.9 / 11.0)$ & ND \\
\hline Total pre-flood ecosystem & & 602.9 & $7(-103 / 110)$ & $7.6(6.2 / 8.9)$ & $-27(-10 /-52)$ \\
\hline
\end{tabular}

\footnotetext{
${ }^{a}$ Negative values represent $\mathrm{C}$ sink. Values between parentheses correspond to lower and upper limit estimates. ND denotes not determined.
} 
sedimenting $\mathrm{C}$ and may therefore overestimate the true retentive capacity of the reservoir, and thus the reservoir $\mathrm{C}$ sink/source balance should be viewed as conservative. The overall impact of the reservoir creation on the $\mathrm{C}$ source/sink balance can be therefore calculated as:

[13] Net reservoir C footprint $=$ Reservoir C sink/source balance - Pre-flood C sink/source balance.

[14] Data collected both before and after flooding showed that dissolved organic carbon (DOC), particulate matter and partial pressure of $\mathrm{CO}_{2}\left(\mathrm{CO}_{2}\right)$ concentrations in the Eastmain River upstream and downstream of the flooded basin remain similar (within $+/-10 \%$ ), which suggest small changes in the net export via the river from the study basin. In our calculations of net reservoir impact we have therefore only considered changes in $\mathrm{CO}_{2}$ and $\mathrm{CH}_{4}$ emissions and $\mathrm{C}$ storage within the flooded basin, and have not included differences between the input and outputs of $\mathrm{C}$ to and from the basin via the Eastmain River, which were too small to be resolved, and which were small also relative to other fluxes.

[15] We used a single, average Pre-flood C sink/source balance for all calculations, whereas we calculated the reservoir $\mathrm{C}$ sink/source balance for each of the 4 study years post flooding. The net reservoir $\mathrm{C}$ footprint represents the net changes in $\mathrm{CO}_{2}$ and $\mathrm{CH}_{4}$ flux which includes the actual measured emissions plus the loss of the sinks or sources of $\mathrm{CO}_{2}$ and $\mathrm{CH}_{4}$ that were present in the pre-flood landscape, and thus represent the "excess" emissions directly associated with the creation and operation of the reservoir.

[16] The results presented here combine multiple research components that were carried out in parallel by the different groups within the team over the 7-year study period. Portions of the data used in this final mass balance have been published before (as referenced), others are in the process of being published, and yet other data components are unpublished and presented here for the first time.

\subsection{Flux Measurements and Calculations}

\subsubsection{Streams, Rivers, and Lakes}

[17] We sampled a wide range of natural aquatic ecosystems, including lakes, streams and rivers of varying sizes, starting in 2005 (one year before flooding), and continuing until 2009, including winter sampling carried out in 2008 (see section S2 in Text S1 in the auxiliary material for details of aquatic sampling). Diffusive air-water $\mathrm{CO}_{2}$ and $\mathrm{CH}_{4}$ fluxes can be adequately modeled as a Fickian diffusive process (also known as the Thin Boundary Layer method, TBL) and were determined from the difference in partial pressures of $\mathrm{CO}_{2}\left(p \mathrm{CO}_{2}\right)$ and of $\mathrm{CH}_{4}\left(p \mathrm{CH}_{4}\right)$ in the surface water relative to that of the atmosphere combined with an appropriate gas transfer coefficient $\left(\mathrm{k}_{600}\right)$ [Hesslein, 2005; Cole and Prairie, 2009]. The surface water $p \mathrm{CO}_{2}$ was measured using a non-dispersive infrared (NDIR) instrument (PP-System EGM-4) coupled to a gas equilibrator, and $p \mathrm{CH}_{4}$ using gas chromatography (see section S3 in Text S1 for details on gas measurements and diffusive flux calculations). In addition, we made direct measurements of diffusive fluxes in lakes using floating chambers (see section S3 in Text S1 for full description of approach and calculations). The chamber measurements may be affected by turbulence and chamber design [Vachon et al., 2010], whereas the TBL estimates are strongly influenced by assumptions concerning wind speed and gas exchange coefficients [Duchemin et al.,
1995; Matthews et al., 2003], so we combine both types of estimates to better bracket aquatic emissions.

[18] Annual values were estimated from daily summer fluxes by assuming an average ice-free period in the region of 215 days, and that the $\mathrm{C}$ pool which has accumulated under the winter ice is released rapidly within the first month following the ice break and represents $30 \%$ of the annual emission as suggested by gas partial pressure data from both natural lakes (V. Ducharme-Riel et al., The contribution of winter under-ice and summer hypolimnetic $\mathrm{CO}_{2}$ accumulation to the annual $\mathrm{CO}_{2}$ budget of temperate and boreal lakes in Québec, submitted to Ecosystems, 2011) and the reservoir [Demarty et al., 2009; Bastien et al., 2011a].

[19] We further measured the $\mathrm{C}$ sedimentation rates in lakes using sediment traps (two traps per mooring) deployed for more than two months during the summer period of 2008 at the deepest locations of eleven reference lakes situated in the immediate vicinity of the reservoir (C. R. Teodoru et al., Depositional fluxes and sources of particulate carbon and nitrogen in natural lakes and a young boreal reservoir in Northern Québec, submitted to Biogeochemistry, 2012). Long-term $\mathrm{C}$ sequestration rates were calculated as the difference between these gross $\mathrm{C}$ sedimentation rates and the fraction of $\mathrm{C}$ that is eventually respired in the benthos [Brothers et al., 2011]. While the mean rates of $\mathrm{C}$ sequestration represent an area-weighted average, the upper and lower limits of $\mathrm{C}$ accumulation correspond to the minimum and maximum recorded values.

\subsubsection{Forests}

[20] We estimated the net ecosystem exchange (NEE) of $\mathrm{CO}_{2}$ for the major forest types that are present in the Eastmain region. The dominant forest is represented by coniferous black spruce (Picea mariana Miller BSP) closed canopy for which we measured NEE continuously starting in August 2006 up to 2009 using eddy covariance tower (see section S4 in Text S1 for details). An overall annual $\mathrm{CO}_{2}$ budget was calculated by accumulating the NEE over each year of measurements. Details of eddy covariance data processing and flux calculations are described by Bonneville et al. [2008] and Barr et al. [2004]. Since there was a relatively large variation in stand ages and stand types (i.e., black spruce, jack pine) of the coniferous forest in the region, a more robust calculation of the regional $\mathrm{CO}_{2}$ budget for the coniferous forest within the Eastmain-1 was obtained by combined our measured NEE (eddy covariance tower - three years data for black spruce) with literature value from other representative boreal black spruce forests (i.e., jack pine Pinus banksiana Lamb.) of different ages [Arain et al., 2002; Amiro et al., 2006; Yuan et al., 2008]. The area-weighted average value for the entire coniferous forest was derived taking into account the spatial and temporal variability in NEE for these different coniferous forest types. For deciduous forests, the $\mathrm{CO}_{2}$ budget was derived from literature data on eddy covariance NEE measurements made in boreal aspen forests [Arain et al., 2002; Amiro et al., 2006; Barr et al., 2007]. Literature data from similar regions were also used to estimate the $\mathrm{CO}_{2}$ budget for burned forests of different ages [Amiro et al., 2006; Mkhabela et al., 2009]. Since it is recognized that the forest fire cycle in this region is around 100 years [Bergeron et al., 2004], we assumed that about 1\% of the total area (coniferous + deciduous + previously burnt), would burn every year, and that $50 \%$ of the related biomass 
(but not soil carbon) burned would be emitted to the atmosphere as $\mathrm{CO}_{2}$. Forest $\mathrm{CH}_{4}$ fluxes were estimated from chamber measurements of soil $\mathrm{CH}_{4}$ fluxes that were taken in 2007 in regionally representative coniferous, deciduous and burned forest sites in the surrounding areas of the reservoir (see details of soil chamber measurements in section S4 in Text S1).

\subsubsection{Wetlands}

[21] Chamber measurements of NEE and of $\mathrm{CH}_{4}$ fluxes were performed in six regionally representative peatlands in 2005, and in three peatlands between 2006 and 2008 (as 3 of them were inundated in 2006) plus in one peatland ( $\mathrm{Lac} \mathrm{Le}$ Caron peatland) in 2009. Fluxes were measured using static chambers over five different microforms (high hummocks, low hummocks, hollows, lawns, pools) representative of the spatial heterogeneity of the ecosystems, and sampling was carried out during the growing season (from May to October). Wintertime daily average fluxes were assumed to be $10 \%$ of the growing season fluxes [Pelletier, 2005; Pelletier et al., 2007, 2011]. Growing season fluxes, photosynthetically active radiation (PAR) and other parameters were used to estimate overall annual fluxes. Details on the techniques, equations and calculations are described by Pelletier et al. [2007, 2009, 2011]. From June 2008 to December 2009, NEE- $\mathrm{CO}_{2}$ was also measured directly with a portable eddy covariance tower. Data processing and annual $\mathrm{CO}_{2}$ budget calculations were performed similarly to those for the forest ecosystems (see section S4 in Text S1 for details). The bog $\mathrm{CO}_{2}$ budget is an average of the fluxes measured for each year from 2006 to 2009 using the chamber data, and the average annual $\mathrm{CO}_{2}$ budget derived from the flux tower data collected in 2008 and 2009. The fen $\mathrm{CO}_{2}$ budget was obtained by averaging the chamber fluxes measured in 2006 and 2008. The overall regional wetland $\mathrm{CO}_{2}$ budget consists of the area-weighted sum of the $\mathrm{CO}_{2}$ and $\mathrm{CH}_{4}$ budget for both bogs and fens. Swamps/marshes category was given the average peatlands value, because no measurements were carried out in these systems, but they represent less than $10 \%$ of the total aquatic area so they have limited impact on the overall regional budget.

\subsubsection{Eastmain-1 Reservoir}

[22] Sampling of the Eastmain-1 reservoir was carried out during the ice-free period of the years 2006, 2007, 2008 and 2009 with three extensive sampling campaigns per year: Spring (May to June), summer (July to August), and autumn (September to October). More than 100 different sites were selected in a stratified design to cover all major flooded ecosystem types within the reservoir surface. This sampling strategy was chosen to obtain an extensive coverage of the reservoir surface reducing the uncertainties around mean values of measured variables and to take into account the spatial heterogeneity in surface fluxes that is related to the former landscape types [Teodoru et al., 2011]. At each sampling site we determined the $\mathrm{C}$ gas $\left(\mathrm{CO}_{2}\right.$ and $\left.\mathrm{CH}_{4}\right)$ partial pressures and we used these surface concentrations to estimate diffusive fluxes based on the TBL method described earlier for the natural aquatic ecosystem; we measured diffusive fluxes at each site using floating chambers, also as described above. The inter-annual variability, spatial heterogeneity and the trend of both total reservoir flux and the underlying processes are thus embedded within the time series measurements over 4 years period [Teodoru et al., 2011; Bastien et al., 2011a].

[23] Besides estimating diffusive fluxes, we used empirical estimates of degassing fluxes at the turbines and spillway from the time series $p \mathrm{CO}_{2}$ and $p \mathrm{CH}_{4}$ concentrations of the inlet water of the turbines measured continuously from September 2006 to December 2009 with an automated system installed at the Eastmain-1 powerhouse [Bastien et al., 2011a]. The assumption used in degassing flux calculations was that all the excess $p \mathrm{CO}_{2}$ and $p \mathrm{CH}_{4}$ (relative to the atmospheric values of $380 \mathrm{ppmv}$ for $\mathrm{CO}_{2}$ and $1.77 \mathrm{ppmv}$ for $\mathrm{CH}_{4}[$ Forster et al., 2007] was emitted into the atmosphere at the turbines or immediately downstream the powerhouse [Roehm and Tremblay, 2006]. The measured $p \mathrm{CO}_{2}$ and $p \mathrm{CH}_{4}$ during 2010 and 2011 in the river downstream of the dam was in the range of about 600 ppmv $\mathrm{CO}_{2}$ and $2 \mathrm{ppmv}$ $\mathrm{CH}_{4}$ [Bastien et al., 2011b], suggesting a slight overestimation of the degassing flux. These relatively high river concentrations may also have been the result of lateral inputs and high rates of replenishment as observed in most boreal rivers in Quebec (C. R. Teodoru et al., manuscript in preparation, 2012). Annual degassing emissions were thus calculated as the product of monthly mean water excess $\mathrm{CO}_{2}$ and $\mathrm{CH}_{4}$ concentrations and the mean water discharge. Upper and lower limits were estimated using the standard deviation values from the mean. Details on the equations and calculations are given by Demarty et al. [2009].

[24] Bubble-mediated $\mathrm{CH}_{4}$ fluxes were measured in the Eastmain-1 reservoir from June to September 2008 using 50 submerged inverted funnels deployed along eight transects to cover four major flooded ecosystems: forest, peatland, lakes and river. The accumulated gas was sampled every 2 to 3 weeks (156 samples) and analyzed for $\mathrm{CH}_{4}$ concentration using a gas chromatograph. As $\mathrm{CH}_{4}$ bubbles were extremely rare (only three funnels trapped $\mathrm{CH}_{4}$ bubbles and only one funnel had detectable concentrations), the range variability of gross bubble emissions (lower, mean and upper limits) for the entire reservoir was estimated by multiplying the average measured flux with $1 \%, 5 \%$ and $10 \%$, respectively, of the reservoir surface of $603 \mathrm{~km}^{2}$. This percentage range described best the variability in the relative contribution of shallow waters to the total reservoir surface, where increased water temperature due to shallower conditions may favor $\mathrm{CH}_{4}$ bubble production.

[25] As with natural lakes, net $\mathrm{C}$ accumulation in the reservoir was estimated from the gross $\mathrm{C}$ sedimentation flux measured in fourteen sediment traps installed at various locations in the reservoir during the summer period of 2008 minus the fraction that is eventually respired in the benthos. As with the other fluxes, we calculated the mean annual sediment $\mathrm{C}$ accumulation in the reservoir by extrapolating the open water measurements to 215 days, assuming that sediment $\mathrm{C}$ accumulation during the ice-cover (150 days) represents $30 \%$ of the annual sink. The upper and lower estimates correspond to the maximum and minimum measured rates of $\mathrm{C}$ deposition, whereas the mean value is integrated (weighted average) over the reservoir area. Detailed information on trends, rates and the origin of $\mathrm{C}$ in the reservoir as well as the eleven reference lakes are described by Teodoru et al. (submitted manuscript, 2012).

[26] All gas concentrations or fluxes are reported as $\mathrm{C}-\mathrm{CO}_{2}$ and $\mathrm{C}-\mathrm{CH}_{4}$, respectively. In this paper we use the atmospheric 
convention - i.e., C fluxes to the atmosphere are expressed with a positive sign, and net $\mathrm{C}$ uptake from the atmosphere is expressed with a negative sign. For the calculation of net $\mathrm{C}$ emissions per unit energy generated, we transformed $\mathrm{C}-\mathrm{CH}_{4}$ to $\mathrm{C}-\mathrm{CO}_{2}$ equivalents $\left(\mathrm{C}-\mathrm{CO}_{2}\right.$ eq. $)$ using a conversion factor of 8.384 combining the ratio of their molecular weights, and 100 years global warming potential (GWP) of methane of 23 [Intergovernmental Panel on Climate Change, 1996]. Annual estimates were calculated using mean values assuming a normal distribution of variables.

[27] The entire basin was mapped using digitized maps (National Topographic Data Base, scale 1:50,000, www. geogratis.cgdi.gc.ca/) and characterized for different terrestrial and aquatic types using the hydrological and topographical extensions in ArcMap GIS 9.2. Statistical analyses of all variables presented here (i.e., errors in the analytic method, errors in the temporal interpolations, errors in the interpretation of the land classes, etc), were carried out using JMP ${ }^{@} 7$ (SAS Institute, Carry, NC, USA).

\section{Results and Discussion}

\subsection{Pre-Flood Fluxes}

[28] All three major components of the aquatic network (rivers, lakes and streams) were consistently net sources of both $\mathrm{CO}_{2}$ and $\mathrm{CH}_{4}$ to the atmosphere. On an annual basis, gross surface $\mathrm{CO}_{2}$ emissions for the Eastmain River were estimated to fluctuate from 280 to $445 \mathrm{mg} \mathrm{C} \mathrm{m}^{-2} \mathrm{~d}^{-1}$ (mean $398 \mathrm{mg} \mathrm{C} \mathrm{m}^{-2} \mathrm{~d}^{-1}$ ), while much smaller $\mathrm{CH}_{4}$ fluxes ranged between 0.8 and $1.1 \mathrm{mg} \mathrm{C} \mathrm{m}^{-2} \mathrm{~d}^{-1}$ (mean $1.0 \mathrm{mg} \mathrm{C} \mathrm{m}^{-2}$ $\mathrm{d}^{-1}$ ). Area-weighted average $\mathrm{CO}_{2}$ emissions from the lakes in the region varied within a very narrow range of between 230 and $247 \mathrm{mg} \mathrm{C} \mathrm{m}^{-2} \mathrm{~d}^{-1}$ (mean $240 \mathrm{mg} \mathrm{C} \mathrm{m}^{-2} \mathrm{~d}^{-1}$ ), and again $\mathrm{CH}_{4}$ fluxes were much lower but slightly higher than river emissions, ranging between 0.9 and $4.2 \mathrm{mg} \mathrm{C} \mathrm{m}^{-2} \mathrm{~d}^{-1}$ (mean $2.7 \mathrm{mg} \mathrm{C} \mathrm{m}^{-2} \mathrm{~d}^{-1}$ ). These estimates are in good agreement with previous studies of similar boreal systems [Tremblay et al., 2005a; Roehm et al., 2009; Tranvik et al., 2009; Karlsson et al., 2010; Bastviken et al., 2011]. The estimated net $\mathrm{C}$ accumulation rates in lake sediments were in the order of -10 to $-51 \mathrm{mg} \mathrm{C} \mathrm{m}^{-2} \mathrm{~d}^{-1}$ (mean $-27 \mathrm{mg} \mathrm{C}$ $\mathrm{m}^{-2} \mathrm{~d}^{-1}$ ), and thus represented only around $10 \%$ of lake $\mathrm{C}$ emissions, a pattern that has also been previously reported [Kortelainen and Pajunen, 2000; Kortelainen et al., 2004; von Wachenfeldt and Tranvik, 2008]. Stream areal emissions were the highest among all natural aquatic ecosystems, with $\mathrm{CO}_{2}$ fluxes ranging from 1115 to over $6000 \mathrm{mg} \mathrm{C} \mathrm{m}^{-2} \mathrm{~d}^{-1}$ (mean $2750 \mathrm{mg} \mathrm{C} \mathrm{m} \mathrm{m}^{-2}$ ), consistent with previous observation [Jonsson et al., 2007; Teodoru et al., 2009]. However, due to their small areal extent relative to other types of aquatic system in this particular basin, the overall contribution of streams to total aquatic $\mathrm{CO}_{2}$ emissions was relatively small (about 7\%). We did not measure $\mathrm{CH}_{4}$ fluxes in streams. However, based on the above example of $\mathrm{CO}_{2}$ fluxes we have assumed that stream $\mathrm{CH}_{4}$ emissions, even if higher than river or lake fluxes, did not represent a major component of the overall aquatic $\mathrm{CH}_{4}$ balance. Subsequent work of our group in other boreal areas tends to support this assumption (P. del Giorgio, unpublished data, 2011).

[29] We used the areal coverage of each type of aquatic system within the pre-flood basin (Table 1) to estimate the area-weighted average $\mathrm{CO}_{2}$ and $\mathrm{CH}_{4}$ emissions for the entire aquatic network that existed prior to flooding, which ranged from 240 to $400 \mathrm{mg} \mathrm{C} \mathrm{m}^{-2} \mathrm{~d}^{-1}$ of $\mathrm{CO}_{2}$ (mean $335 \mathrm{mg} \mathrm{C} \mathrm{m}^{-2}$ $\mathrm{d}^{-1}$ ), and between 0.9 and $2.5 \mathrm{mg} \mathrm{C} \mathrm{m}^{-2} \mathrm{~d}^{-1}$ of $\mathrm{CH}_{4}$ (mean $1.7 \mathrm{mg} \mathrm{C} \mathrm{m}^{-2} \mathrm{~d}^{-1}$ ), respectively (Figure 2).

[30] The estimated total NEE for the entire forest components ranged from -250 to $15.5 \mathrm{mg} \mathrm{C} \mathrm{m}^{-2} \mathrm{~d}^{-1}$ (mean $-117 \mathrm{mg} \mathrm{C} \mathrm{m}^{-2} \mathrm{~d}^{-1}$, Table 1), in good agreement with previous reports for similar boreal landscapes [Blais et al., 2005; Amiro et al., 2006; Barr et al., 2007; Yuan et al., 2008; Mkhabela et al., 2009]. The range of NEE for the wetland components was similar to that of the forest, in the order of -218 to $14.2 \mathrm{mg} \mathrm{C} \mathrm{m}^{-2} \mathrm{~d}^{-1}$ (mean $-102 \mathrm{mg} \mathrm{C} \mathrm{m}^{-2}$ $\mathrm{d}^{-1}$ ) and similar with previous estimates for northern peatlands [Jonsson et al., 2007; Roulet et al., 2007; Nilsson et al., 2008; Koehler et al., 2009; Buffam et al., 2011]. Taken together, the terrestrial (forest + wetland) ecosystems prior to flooding were collectively a moderate sink of $\mathrm{CO}_{2}$, in the order of $-113 \mathrm{mg} \mathrm{C} \mathrm{m}^{-2} \mathrm{~d}^{-1}$ (between -241 to $15 \mathrm{mg} \mathrm{C}$ $\mathrm{m}^{-2} \mathrm{~d}^{-1}$ ) or $-102 \mathrm{mg} \mathrm{C} \mathrm{m}^{-2} \mathrm{~d}^{-1}$ (between -217 to $14 \mathrm{mg} \mathrm{C}$ $\mathrm{m}^{-2} \mathrm{~d}^{-1}$ ) if the Non-Soil Forest area is included (Table 1 and Figure 2). These average values are twice as high compared to terrestrial NEE calculated for a subarctic Swedish catchment [Christensen et al., 2007], three to five times lower than similar catchments in boreal Sweden [Jonsson at al., 2007], and northern temperate USA [Buffam et al., 2011], and close to the global estimate of about $80 \mathrm{mg} \mathrm{C} \mathrm{m}^{-2} \mathrm{~d}^{-1}$ [Battin et al., 2009]. Considering that forest fires in this region contribute annually on the order of 15 to $28 \mathrm{mg} \mathrm{C} \mathrm{m}^{-2} \mathrm{~d}^{-1}$ of $\mathrm{CO}_{2}$ (mean $21 \mathrm{mg} \mathrm{C} \mathrm{m}^{-2} \mathrm{~d}^{-1}$ ), the rate of $\mathrm{CO}_{2}$ uptake by the terrestrial ecosystems would decrease slightly to an average of $-88 \mathrm{mg} \mathrm{C} \mathrm{m}^{-2} \mathrm{~d}^{-1}\left(-207\right.$ to $\left.32 \mathrm{mg} \mathrm{C} \mathrm{m}^{-2} \mathrm{~d}^{-1}\right)$ if fire is incorporated. Due to the relatively large $\mathrm{CH}_{4}$ flux from wetlands of $39 \mathrm{mg} \mathrm{C} \mathrm{m}^{-2} \mathrm{~d}^{-1}$ (in agreement with $\sim 28 \mathrm{mg} \mathrm{C}$ $\mathrm{m}^{-2} \mathrm{~d}^{-1}$ of Buffam et al. [2011]) relative to the low sink in forest soils $\left(-0.22 \mathrm{mg} \mathrm{C} \mathrm{m}^{-2} \mathrm{~d}^{-1}\right)$, the pre-flood combined terrestrial (forest + wetland + mineral soil) components of the landscape were on average a source of approximately $9.5 \mathrm{mg}$ $\mathrm{C} \mathrm{m}^{-2} \mathrm{~d}^{-1}$ of $\mathrm{CH}_{4}$ (Table 1).

[31] The balance of all $\mathrm{C}$ sources and sinks of the aquatic and terrestrial ecosystems, integrated over the entire landscape, suggests that the pre-flood basin was a small source of both $\mathrm{CO}_{2}$ and $\mathrm{CH}_{4}$, of approximately $7 \mathrm{mg} \mathrm{C} \mathrm{m}^{-2} \mathrm{~d}^{-1}$ of $\mathrm{CO}_{2}$ (or $17 \mathrm{mg} \mathrm{C} \mathrm{m}^{-2} \mathrm{~d}^{-1}$ if forest fires are considered) and of $7.6 \mathrm{mg} \mathrm{C} \mathrm{m}^{-2} \mathrm{~d}^{-1}$ of $\mathrm{CH}_{4}$ (Figure 2). The upper and lower limits around this central value of the pre-flood $\mathrm{C}$ balance (Table 1 , numbers in parentheses) were determined by combining the lowest emission estimates with the highest $\mathrm{C}$ uptake estimates (to determine the upper limit), and the highest emission estimates with the lowest $\mathrm{C}$ uptake estimates (to determine the lower limit). Although these confidence limits represent the most extreme scenarios possible within the confines of our measurements (and thus are not statistical intervals), it is clear that the calculated small net $\mathrm{CO}_{2}$ source of the overall landscape cannot be distinguished from zero and that the reservoir area as a whole can be considered carbon-neutral prior to flooding. This is unlikely to be a general characteristic of the entire region however, for it is highly influenced by the high emissions of the Eastmain River, which itself occupies about $14 \%$ of the pre-flood basin area. Large rivers in northern Québec occupy less than 1.5\% of the boreal landscape, so this overall boreal landscape is probably a net sink for carbon as indicated by the results of 

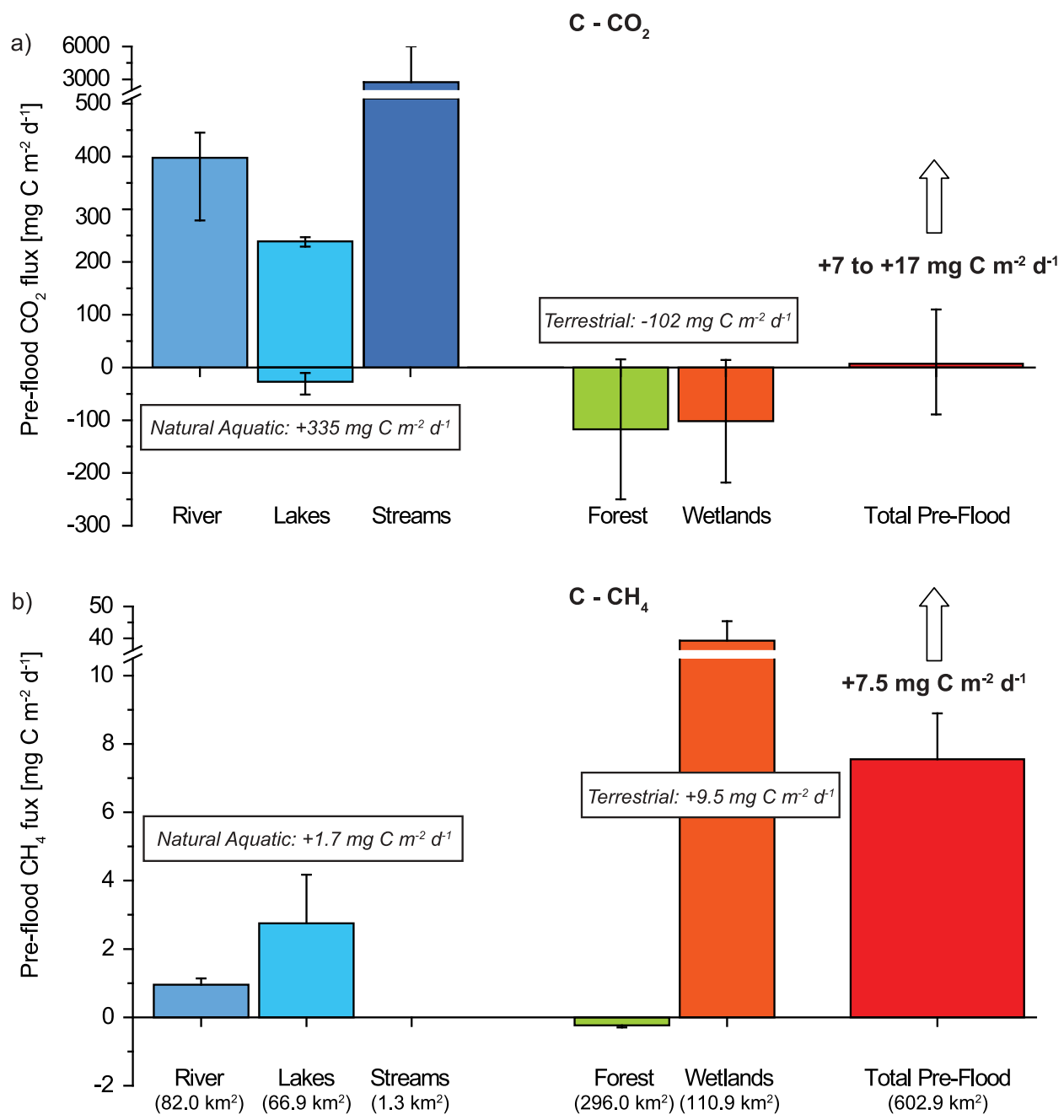

Figure 2

Figure 2. Range variability (minimum, mean and maximum) of (a) gross $\mathrm{CO}_{2}$ and (b) $\mathrm{CH}_{4}$ fluxes for each individual component of natural aquatic (river, lakes and streams) and terrestrial (forest and wetland) ecosystem. The resulting pre-flood $\mathrm{CO}_{2}$ and $\mathrm{CH}_{4}$ fluxes represent weighted averages integrated over the reservoir area.

similar studies of Swedish subarctic and boreal catchments [Christensen et al., 2007; Jonsson at al., 2007], and northern temperate USA [Buffam et al., 2011].

\subsection{Post-Flood Fluxes}

[32] Surface water gas concentrations and air/water gas emissions in the reservoir were highly variable, both spatially and temporally over the 4-year study period. The various ecosystems that existed prior to impoundment have now been incorporated in the Eastmain-1 Reservoir, and have been shown to influence strongly both the magnitude and the spatial patterns of $\mathrm{CO}_{2}$ emissions in the reservoir [Teodoru et al., 2011; Brothers et al., 2012]. The highest $\mathrm{CO}_{2}$ fluxes were measured during the first year after flooding (2006) when the largest spatial heterogeneity was also encountered (up to one order of magnitude) [Teodoru et al., 2011].

[33] Areal-weighted average $\mathrm{CO}_{2}$ fluxes for the entire reservoir reached $2364 \mathrm{mg} \mathrm{C} \mathrm{m}^{-2} \mathrm{~d}^{-1}$ in 2006 and decreased to $1420 \mathrm{mg} \mathrm{C} \mathrm{m}^{-2} \mathrm{~d}^{-1}$ in $2007,1056 \mathrm{mg} \mathrm{C} \mathrm{m}^{-2} \mathrm{~d}^{-1}$ in 2008 and $888 \mathrm{mg} \mathrm{C} \mathrm{m}^{-2} \mathrm{~d}^{-1}$ in 2009 (Table 2). Despite this relatively sharp decrease with reservoir age, surface $\mathrm{CO}_{2}$ fluxes in 2009 were still 3 to fourfold higher than the average fluxes observed for lakes in the region (Table 1) [see also Brothers et al., 2011]. Applying the inverse relationship between $p \mathrm{CO}_{2}$ and lake size [Roehm et al., 2009], the degree of supersaturation and the corresponding fluxes observed in the reservoir are much larger than what would be expected of a lake of similar size. Due to the relatively shallow and predominantly oxic nature of the reservoir, diffusive $\mathrm{CH}_{4}$ fluxes were generally low and quite stable, ranging from $7.3 \mathrm{mg} \mathrm{C}$ $\mathrm{m}^{-2} \mathrm{~d}^{-1}$ in $2006,6.2 \mathrm{mg} \mathrm{C} \mathrm{m}^{-2} \mathrm{~d}^{-1}$ in $2007,6.9 \mathrm{mg} \mathrm{C} \mathrm{m}^{-2}$ $\mathrm{d}^{-1}$ in 2008 and $10.5 \mathrm{mg} \mathrm{C} \mathrm{m} \mathrm{d}^{-1}$ in 2009 (Table 2). Although those diffusive $\mathrm{CH}_{4}$ fluxes in the reservoir seems low, they were fourfold higher than the $\mathrm{CH}_{4}$ emissions for lakes in the region, and similar to those of pre-flood terrestrial (forest + wetland + mineral soil) components of the landscape (Table 1).

[34] We explored bubble-mediated fluxes in the reservoir, but out of 50 funnels and 156 samples analyzed during the summer period of 2008 , only three funnels collected $\mathrm{CH}_{4}$ 
bubbles. Ebullition flux calculation based on the funnel's surface area and exposure time resulted in an average value of $1.7 \mathrm{mg} \mathrm{C} \mathrm{m}^{-2} \mathrm{~d}^{-1}$ (Table 2), which is fourfold lower than the corresponding average diffusive $\mathrm{CH}_{4}$ flux of 2008 . Bubble-mediated $\mathrm{CH}_{4}$ fluxes for the entire reservoir were calculated by multiplying the average flux with $1 \%, 5 \%$ and $10 \%$, respectively, of the reservoir area to yield a lower, mean

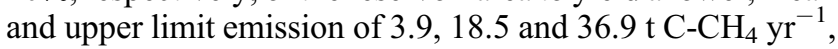
respectively. Compared with the total amount of $\mathrm{CH}_{4}$ emitted into the atmosphere during 2008 through diffusive fluxes, ebullition is small, accounting for only between 1.5 to $7.5 \%$. This would suggest that ebullition is a minor pathway for $\mathrm{CH}_{4}$ evasion in this boreal reservoir, in contrast with other types of aquatic systems [Bastviken et al., 2011].

[35] The rates of sediment $\mathrm{C}$ accumulation, derived by from sediment traps data given by Teodoru et al. (submitted manuscript, 2012) and benthic respiration rates [Brothers et al., 2012], were highly heterogeneous within the reservoir, varying between -30 and $-142 \mathrm{mg} \mathrm{C} \mathrm{m}^{-2} \mathrm{~d}^{-1}$ (arealweighted average: $-90 \mathrm{mg} \mathrm{C} \mathrm{m}^{-2} \mathrm{~d}^{-1}$, Table 2), and are in agreement with previous reservoir sedimentation studies in the region [Houel et al., 2006]. The estimated rates of $\mathrm{C}$ accumulation in the reservoir were three to four times higher than the equivalent rates in the surrounding lakes, perhaps due to increased external loads and littoral sediment re-suspension, but were small relative to the diffusive $\mathrm{C}$ fluxes in the reservoir (mean surface emission to burial ratio of 12).

[36] In addition to diffusive and bubble fluxes, $\mathrm{CO}_{2}$ and $\mathrm{CH}_{4}$ emissions also occurred as degassing at the turbine, spillway and downstream of the powerhouse, and these were estimated to reach $1101 \mathrm{t} \mathrm{C} \mathrm{yr}^{-1}$ of $\mathrm{CO}_{2}$ and $87 \mathrm{t} \mathrm{C} \mathrm{yr}^{-1}$ of $\mathrm{CH}_{4}$ during the first year, but these estimates cover the period when the reservoir was being filled and there was very little water released through the turbines. The degassing emissions were much higher in subsequent years $\left(15,068 \mathrm{t} \mathrm{C} \mathrm{yr}^{-1} \mathrm{CO}_{2}\right.$ and $389 \mathrm{tC} \mathrm{yr}^{-1} \mathrm{CH}_{4}$ in $2007,14,479 \mathrm{tC} \mathrm{yr}^{-1} \mathrm{CO}_{2}$ and $387 \mathrm{t}$ $\mathrm{C} \mathrm{yr}^{-1} \mathrm{CH}_{4}$ in 2008 and $9800 \mathrm{t} \mathrm{C} \mathrm{yr}^{-1} \mathrm{CO}_{2}$ and $273 \mathrm{t} \mathrm{C} \mathrm{yr}^{-1}$ $\mathrm{CH}_{4}$ in 2009). For the purpose of comparison, these annual degassing rates at the powerhouse (in $\mathrm{t}_{\mathrm{yr}}^{-1}$ ) are expressed in Table 2 as areal fluxes $\left(\mathrm{mg} \mathrm{C} \mathrm{m}^{-2} \mathrm{~d}^{-1}\right)$ relative to the total reservoir area. It is clear that degassing emissions represent a relatively small fraction of the total reservoir $\mathrm{C}$ emissions, representing 5 to $6 \%$ of the total diffusive $\mathrm{CO}_{2}$ fluxes, and 12 to $30 \%$ of total $\mathrm{CH}_{4}$ emissions.

[37] The net balance between gross reservoir surface fluxes, sediment $\mathrm{C}$ fluxes, degassing, and bubble-mediated emissions indicates that during the first year after flooding (2006), the Eastmain-1 reservoir was an overall net source of both $\mathrm{CO}_{2}$ and $\mathrm{CH}_{4}$, in the order of $2280 \mathrm{mg} \mathrm{C} \mathrm{m}^{-2} \mathrm{~d}^{-1}$ and $7.8 \mathrm{mg} \mathrm{C} \mathrm{m}^{-2} \mathrm{~d}^{-1}$, respectively (Table 2 ). The net $\mathrm{CO}_{2}$ emissions declined steeply in subsequent years, to $1390 \mathrm{mg}$ $\mathrm{C} \mathrm{m}^{-2} \mathrm{~d}^{-1}$ in $2007,1032 \mathrm{mg} \mathrm{C} \mathrm{m}^{-2} \mathrm{~d}^{-1}$ in 2008 and $843 \mathrm{mg}$ $\mathrm{C} \mathrm{m}{ }^{-2} \mathrm{~d}^{-1}$ in 2009 , whereas $\mathrm{CH}_{4}$ emissions increased steadily to $8 \mathrm{mg} \mathrm{C} \mathrm{m}^{-2} \mathrm{~d}^{-1}$ in $2007,8.8 \mathrm{mg} \mathrm{C} \mathrm{m}^{-2} \mathrm{~d}^{-1}$ in 2008 and $11.9 \mathrm{mg} \mathrm{C} \mathrm{m}^{-2} \mathrm{~d}^{-1}$ in 2009 . As in the case of preflood $\mathrm{C}$ sink/source balance, the lower and upper ranges of the post-flood balance of each year (Table 2, numbers in parentheses) were calculated by combining the lowest recorded emissions with the highest $\mathrm{C}$ accumulation rates (to derive the lower emission range), and the highest recorded emissions with the lowest $\mathrm{C}$ accumulation rates (to derive the upper emission range). The results of the post-flood balance 

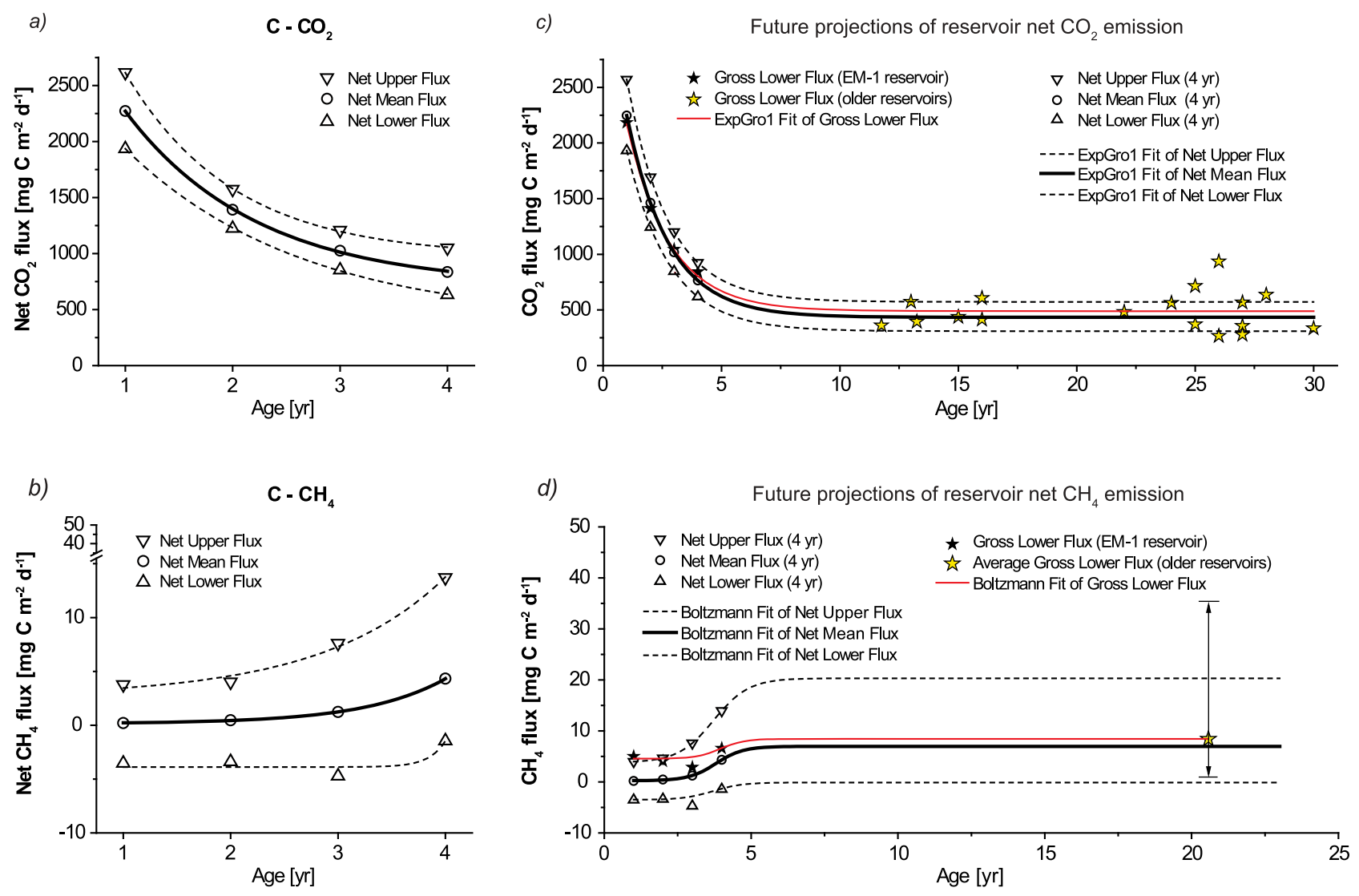

Figure 3

Figure 3. Range variability (upper, mean and lower) of (a) net $\mathrm{CO}_{2}$ and (b) net $\mathrm{CH}_{4}$ fluxes for the Eastmain-1 Reservoir calculated over the initial four years period; and future projection of (c) net $\mathrm{CO}_{2}$ and (d) net $\mathrm{CH}_{4}$ emissions over the expected life span of the reservoir (100 years). In the absence of any significant correlation between gross lower $\mathrm{CH}_{4}$ fluxes from older reservoirs and age, only an average value (gross lower flux, yellow star) was displayed as representative for the entire data set.

clearly show that reservoir $\mathrm{C}$ emissions were dominated by $\mathrm{CO}_{2}$ diffusive fluxes from the water/air interface, that $\mathrm{CH}_{4}$ emissions (both diffusive and ebullition) were small relative to $\mathrm{CO}_{2}$ fluxes, and that the former declined steeply with time after flooding, agreeing with previous reports for boreal and temperate reservoirs [St. Louis et al., 2000; Tremblay et al., 2005a, 2005b].

\subsection{Net Reservoir C Footprint}

[38] The net reservoir $\mathrm{C}$ footprint represents the actual $\mathrm{CO}_{2}$ and $\mathrm{CH}_{4}$ fluxes to the atmosphere over and above the exchanges that existed in the pre-flood landscape, and thus represent the emissions that can be directly attributed to the creation and existence of the reservoir. As stated in the Methods section, these were calculated by subtracting the pre-flood C sink/source balance of the basin, from the postflood C sink/source balance of the reservoir. If overall the pre-flood basin was a net sink of $\mathrm{C}$, then the integrated preflood landscape fluxes need to be added to the net post-flood reservoir fluxes to account for the total change in landscape scale $\mathrm{CO}_{2}$ exchange. Conversely, if the landscape was a source of $\mathrm{C}$ to the atmosphere then the landscape flux needs to be subtracted from the reservoir emissions. We bracketed our best estimates (the mean value) of net reservoir $\mathrm{C}$ footprint, with likely upper and lower limits, by creating two contrasting extreme scenarios: 1) a low emission scenario that combines the lowest reservoir fluxes and highest pre-flood emissions; and 2) a high-emission scenario that combines the highest reservoir fluxes plus the highest pre-flood sinks (or minus the lowest pre-flood emissions). This approach intrinsically provides wider confidence intervals than standard error propagation calculations would yield and we are thus confident that the uncertainty in our projected emissions are both conservative and robust.

[39] The pre-flood emissions suggests that the basin was a small source of both $\mathrm{CO}_{2}$ and $\mathrm{CH}_{4}$, in the range of 7 and $7.6 \mathrm{mg} \mathrm{C} \mathrm{m}^{-2} \mathrm{~d}^{-1}$, respectively (Table 1 ), while the postflood $\mathrm{C}$ sink/source balance indicates that the reservoir was a large net source of $\mathrm{CO}_{2}$, and a relatively small source of $\mathrm{CH}_{4}$ (Table 2). However, taking into consideration the analytical and all the interpolation errors, it is safe to assume that the landscape prior to flooding was effectively carbon neutral. The difference between the pre-flood and post-flood fluxes indicates that the net reservoir $\mathrm{C}$ footprint for Eastmain-1 was initially (2006) a large net source of around $2270 \mathrm{mg} \mathrm{C}$ $\mathrm{m}^{-2} \mathrm{~d}^{-1}$ of $\mathrm{CO}_{2}$, and of only $0.2 \mathrm{mg} \mathrm{C} \mathrm{m} \mathrm{d} \mathrm{d}^{-1}$ of $\mathrm{CH}_{4}$ (Figures $3 \mathrm{a}$ and $3 \mathrm{~b}$ ). The upper and lower scenarios for 2006 suggest a range of variability around these mean 
values of about $\pm 14 \%$ for $\mathrm{CO}_{2}(+343 /-339)$, and of $\pm 94 \%$ $(+3.6 /-3.7)$ for $\mathrm{CH}_{4}$. On an annual base, this translates into a net $\mathrm{C}$ release to the atmosphere due to the Eastmain-1 reservoir of around $5 \times 10^{5}$ t C-CO $\mathrm{CO}_{2}$ and approximately $45 \mathrm{t} \mathrm{C}-\mathrm{CH}_{4}$. The same calculation for subsequent years indicates that net reservoir sink/source balance of $\mathrm{CO}_{2}$ decreased to 1390 $(+180 /-165) \mathrm{mg} \mathrm{C} \mathrm{m}^{-2} \mathrm{~d}^{-1}$ in $2007,1025(+180 /-170) \mathrm{mg}$ $\mathrm{C} \mathrm{m}^{-2} \mathrm{~d}^{-1}$ in 2008 , and $835(+215 /-200) \mathrm{mg} \mathrm{C} \mathrm{m}^{-2} \mathrm{~d}^{-1}$ in 2009 (Figure 3a). Incorporating $\mathrm{CO}_{2}$ fluxes due to forest fires in these calculations results in only a $1 \%$ change in the estimated net reservoir $\mathrm{CO}_{2}$ sink/source balance. The net reservoir $\mathrm{C}$ sink/source balance of $\mathrm{CH}_{4}$ increased with the reservoir age, ranging from $0.5(+3.6 /-3.8) \mathrm{mg} \mathrm{C} \mathrm{m}^{-2} \mathrm{~d}^{-1}$ in 2007, $1.2(+6.4 /-6.0) \mathrm{mg} \mathrm{C} \mathrm{m}^{-2} \mathrm{~d}^{-1}$ in 2008 and $4.3(+9.4 /$ $-5.8) \mathrm{mg} \mathrm{C} \mathrm{m}^{-2} \mathrm{~d}^{-1}$ in 2009 (Figure 3b).

[40] It is difficult at this point to accurately project the course of the reservoir net $\mathrm{CO}_{2}$ sink/source balance beyond the initial four years of this study. The initial trajectory of net $\mathrm{CO}_{2}$ emissions fits extremely well $\left(\mathrm{R}^{2}>0.99\right)$ both a negative exponential with threshold $[\mathrm{F}=\mathrm{C}+\exp (-\mathrm{k} \times \mathrm{T})]$ and a power function $\left(\mathrm{F}=\mathrm{a} \times \mathrm{T}^{-\mathrm{b}}\right)$. Although the fit of these two models is identical in the initial years, they differ markedly over time and there are no statistical reasons for choosing one model over the other. The power model predicts near zero emissions within less than 25 years whereas the exponential model predicts long-term emissions of around $700 \mathrm{mg} \mathrm{C}$ $\mathrm{m}^{-2} \mathrm{~d}^{-1}$. It is clear however that the former scenario is rather unrealistic, since there is empirical evidence that older reservoirs in the same boreal region of northern Québec still emit at rates that vary between 300 and $900 \mathrm{mg} \mathrm{C} \mathrm{m}^{-2} \mathrm{~d}^{-1}$ of $\mathrm{CO}_{2}$, even after 25 to 75 years [Tremblay et al., 2005a]. Therefore, the negative exponential model was considered more appropriate for the projection with reference to the overall objective of the study. Similarly, the early trajectory of $\mathrm{CH}_{4}$ emissions fits a positive linear model, which predicts extremely high $\mathrm{CH}_{4}$ fluxes within 25 years. This is equally unrealistic since gross $\mathrm{CH}_{4}$ fluxes for the same reservoirs rarely exceed $35 \mathrm{mg} \mathrm{C} \mathrm{m}^{-2} \mathrm{~d}^{-1}$.

[41] To further examine the projected long-term trend, we combined our data for the Eastmain-1 reservoir with existing $p \mathrm{CO}_{2}$ and $p \mathrm{CH}_{4}$ data from older reservoirs in the same boreal region of Québec to model the potential trajectory of the net reservoir $\mathrm{C}$ emissions (Figures $3 \mathrm{c}$ and $3 \mathrm{~d}$ ). Since these reported data represent gross fluxes, we had to estimate the corresponding net fluxes so that the data would be comparable to that of Eastmain. First, we derived $\mathrm{CO}_{2}$ fluxes for these older reservoirs based on the measured $p \mathrm{CO}_{2}$ using a TBL model, which provide a lower limit estimate of $\mathrm{CO}_{2}$ fluxes (as described in the Methods section and in section S2 in Text S1). We then developed an empirical linear relationship between the lower gross $\mathrm{CO}_{2}$ fluxes and the net $\mathrm{CO}_{2}$ sink/source balance for the Eastmain-1 reservoir, based on our own estimates, and assumed that this same relationship applies to other boreal reservoirs in the same region. Finally, we applied this empirical relationship to the gross $\mathrm{CO}_{2}$ fluxes calculated for the older boreal reservoirs, in order to obtain an estimate of net $\mathrm{CO}_{2}$ sink/source balance for these reservoirs, and we used these estimates to reconstruct the potential trajectory of net $\mathrm{CO}_{2}$ emissions with time for the Eastmain-1 reservoir.

[42] The model that best fits the combination of Eastmain-1 data (first four years, Figure 3a) and the data from older boreal reservoirs is also a first-order exponential decay with an additive intercept (equation 1) and Figure 3c), rather than either a negative power or normal exponential decline:

$$
\operatorname{NMF}_{(\mathrm{CO} 2)}=433.8+3195.9 \times \exp \left(\text { Age/-1.76), } \quad \mathrm{R}^{2}=0.86\right.
$$

where $\mathrm{NMF}_{(\mathrm{CO} 2)}$ is the net mean $\mathrm{CO}_{2}$ flux in $\mathrm{mg} \mathrm{C} \mathrm{m}^{-2} \mathrm{~d}^{-1}$, and Age represent the number of years after flooding.

[43] We further assumed that the relative differences between the lower, mean and upper emission estimates of the first four years are maintained in time, so that we could extrapolate likely upper and lower limits for the projected fluxes. This empirical modeling of net $\mathrm{CO}_{2}$ fluxes suggests that, after the initial steep decrease during the first five to seven years, the decline in the reservoir net $\mathrm{CO}_{2}$ sink/source balance will decelerate and the fluxes will stabilize after twelve to fifteen years, around a threshold level of about $435(+140 /-120) \mathrm{mg} \mathrm{C} \mathrm{m}^{-2} \mathrm{~d}^{-1}$ (Figure 3c). This level is somewhat lower than that projected only from the initial four yours (approx. 40\% lower) but still two orders of magnitude higher than the integrated emissions of the pre-flooded ecosystem that we estimated for this boreal region (assuming that the terrestrial exchange would not have changed in time). Even though there is a large degree of uncertainty associated with the method assumptions, this approach, which also consider the evolution in time of $\mathrm{C}$ emissions in other (older) reservoirs in the region, adds extra level of confidence to the overall long-term projection. Most certainty, it is therefore safe to assume that this trajectory resemble better the true situation rather than would have been if directly extrapolated from our initial four years alone.

[44] In the case of $\mathrm{CH}_{4}$, we based our projections of net $\mathrm{CH}_{4}$ sink/source balance from Eastmain-1 on $p \mathrm{CH}_{4}$-derived fluxes from older reservoirs in the region with ages between five to eighty years (average twenty years). The results indicate a range variability of gross lower fluxes between 1.7 and $37.5 \mathrm{mg} \mathrm{C} \mathrm{m}^{-2} \mathrm{~d}^{-1}$. In the absence of any significant correlation with the reservoir age, an average gross lower flux of $8.4 \mathrm{mg} \mathrm{C} \mathrm{m}^{-2} \mathrm{~d}^{-1}$ was considered representative for all older reservoirs (Figure 3d, yellow star). Following the same steps described above for $\mathrm{CO}_{2}$ fluxes, the exercise suggests that after an initial exponential increase characteristic of the first six to seven years, reservoir net $\mathrm{CH}_{4}$ emissions would reach a plateau level of around $7.0(+13.4 /-7.1)$ $\mathrm{mg} \mathrm{C} \mathrm{m}{ }^{-2} \mathrm{~d}^{-1}$ (equation (2) and Figure 3d). The resulting model is described by:

$$
\begin{aligned}
N M F_{(C H 4)} & =6.97-6.72 /\{1+\exp [(\text { Age }-3.80) / 0.46]\}, \\
\mathrm{R}^{2} & =0.99
\end{aligned}
$$

where $\mathrm{NMF}_{(\mathrm{CH} 4)}$ represents the net mean $\mathrm{CH}_{4}$ flux in $\mathrm{mg} \mathrm{C}$ $\mathrm{m}^{-2} \mathrm{~d}^{-1}$, and Age is the number of years after flooding. These results suggest that reservoirs continue to emit $\mathrm{C}$ (both $\mathrm{CO}_{2}$ and $\mathrm{CH}_{4}$ ) at a rate that exceeds that of the pre-flood ecosystem. The empirical modeling results presented here represent a first attempt at projecting the long-term net $\mathrm{C}$ emissions resulting from the creation of a hydroelectric reservoir. We are currently developing a process-based model that incorporates, among other factors, climate effects over the lifetime of the reservoir that should allow us to confirm 
a)
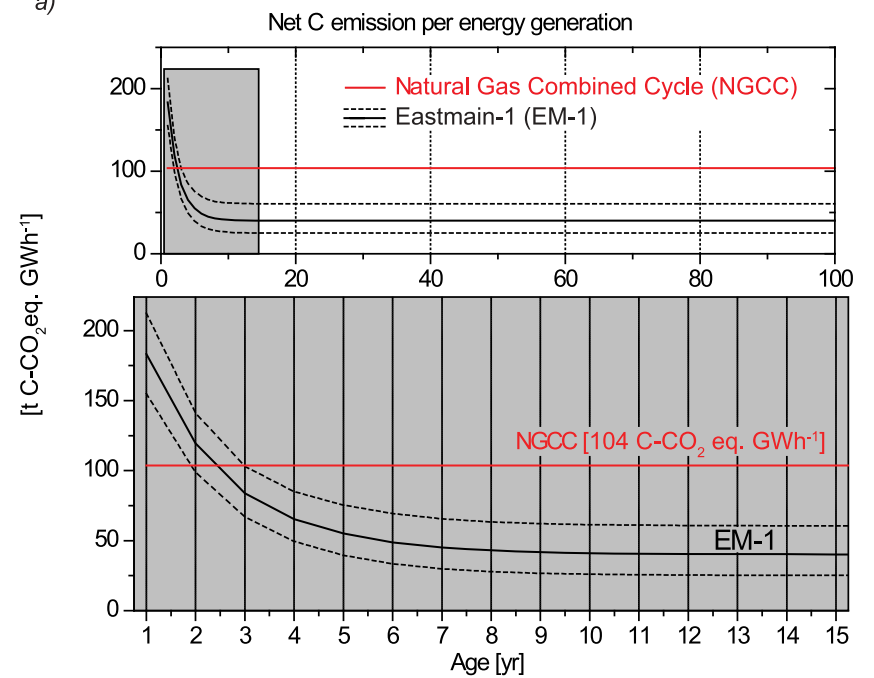

b)

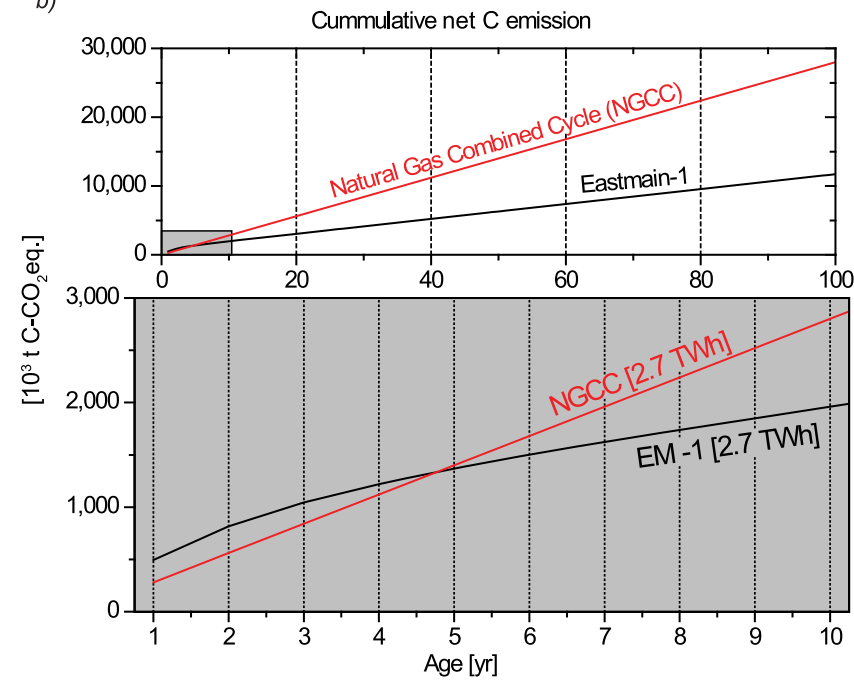

Figure 4

Figure 4. (a) Evolution of net $\mathrm{C}$ emission per energy generation over time for Eastmain-1 powerhouse (2.7 TWh) compared to a natural-gas combined-cycle (NGCC) power station (2.7 TWh, 104 t C-CO eq $\mathrm{GWh}^{-1}$ ). (b) Cumulative net $\mathrm{C}$ emissions for the Eastmain-1 reservoir relative to the equivalent cumulative amount of $\mathrm{C}$ gas emitted by most efficient thermal power plants (NGCC) to generate same amounts of energy (2.7 TWh).

and expand these long-term projections (N. T. Roulet et al., manuscript in preparation, 2012).

\subsection{Net $\mathbf{C}$ Emissions per Energy Generation}

[45] The net $\mathrm{C}$ footprint of this boreal reservoir discussed in previous sections translates into net $\mathrm{C}$ emissions per energy generation of $183 \mathrm{t} \mathrm{C}^{-\mathrm{CO}_{2}} \mathrm{eq} \mathrm{GWh}^{-1}$ in 2006 and

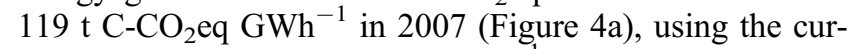
rently installed capacity of $2.7 \mathrm{TWh}^{-1}$. Those rates are about $77 \%$ and $15 \%$ higher, respectively, than the equivalent emissions of around $104 \mathrm{t} \mathrm{C}-\mathrm{CO}_{2}$ eq $\mathrm{GWh}^{-1}$ of the most efficient thermal power plants using a natural-gas combinedcycle (NGCC) [Spath and Mann, 2000; Tremblay et al., 2005b]. These high initial emissions declined steeply over

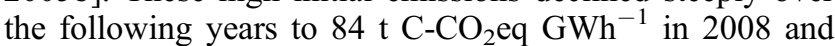
$65 \mathrm{t} \mathrm{C}^{-\mathrm{CO}_{2} \mathrm{eq} \mathrm{GWh}}{ }^{-1}$ in 2009 , which are $20 \%$ and $40 \%$, respectively, below the NGCC level (Figure 4a). Our projections for the following years suggest that these emissions will continue to decline over the next ten to fifteen years, likely reaching an asymptote around an average value of around $40 \mathrm{t} \mathrm{C}-\mathrm{CO}_{2} \mathrm{eq} \mathrm{GWh}^{-1}$ (Figure $4 \mathrm{a}$ ), but the exact pattern of decline has yet to be determined. Extrapolating these trends over the life span of the reservoir (100 years) results in a long-term average net $\mathrm{C}$ emission per energy generation in the range of $43 \mathrm{t} \mathrm{C}-\mathrm{CO}_{2}$ eq $\mathrm{GWh}^{-1}$, with $\mathrm{CH}_{4}$ contributing approximately $10 \%$. Although there is still much uncertainty in these long-term estimates, the upper and

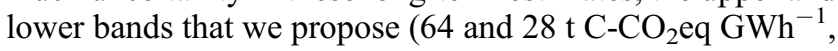
Figure $4 \mathrm{a})$, represent extreme scenarios so that emissions are likely to be within this bracket.

[46] These calculations also raise the question as to the sources of carbon sustaining the projected higher emissions relative to the pre-flood conditions over such long-term. Whereas there is consensus that the initial post-flood upsurge in $\mathrm{CO}_{2}$ and $\mathrm{CH}_{4}$ emissions is the result of the decomposition of labile plant and soil organic matter [Bodaly et al., 2004; Galy Lacaux et al., 1997; Rosenberg et al., 1997], the processes that sustain the long term are less clear and need further exploration. For instance, if the elevated rates are sustained largely by the slow degradation of the flooded soil material, then it is rightly assigned as a consequence of the reservoir creation. If, on the other hand, it is mostly sustained by the biological and photo-chemical mineralization of allochthonous carbon inputs (enhanced because of the longer water residence time of the reservoir) that would have otherwise occurred elsewhere downstream, then it is arguable whether these emissions can be rightfully attributed to the creation of the impoundment or should instead simply viewed as a geographical displacement of these natural emissions. This point is seldom addressed in the current literature on long-term emissions from man-made impoundments but is critical to the proper assessment of human-induced changes to the landscape. We are unable to project empirically the relative importance of these two processes or how it will change over the long-term, but back-of-the-envelope calculations based on an average apparent mass transfer coefficient of $3.2 \mathrm{~m} \mathrm{yr}^{-1}$ for DOC [Dillon and Molot, 1997] suggests that only $10-20 \%$ of the projected long-term C emissions from the Eastmain reservoir can be attributed to natural but displaced emissions. A process-based model is currently under development to further address such question (N. T. Roulet et al., manuscript in preparation, 2012).

[47] While the above results suggest how the annual net emissions per energy production vary through time, for a more direct comparison of energy production alternatives it is more relevant to express how the cumulative $\mathrm{C}$ emissions per unit electricity generation vary throughout the lifespan of the reservoir. According to our calculations and models, it will take over five years (and not only two years as indicated by Figure $4 \mathrm{a}$ ) before the integrated emissions fall below the threshold level of the most efficient thermal power plant (Figure 4b). 
[48] Furthermore, the comparison of $\mathrm{C}$ emissions for different types of energy generation is dependent on the time scale considered. For instance, while during the first year, the Eastmain-1 reservoir was emitting up to $77 \%$ more $\mathrm{C}$ than NGCC, after only 5 years, the emissions were at par with NGCC, and after 25 years, reservoir emissions will be $50 \%$ lower than those of NGCC (Figure 4b). These projections suggest that over its entire projected lifespan (100 years), the Eastmain-1 reservoir will emit the equivalent of $40 \%$ $\left(11,700 \times 10^{3}\right.$ t C- $\mathrm{CO}_{2}$ eq $)$ of the $\mathrm{C}$ emissions that the currently most efficient thermal power plant would have for an equivalent amount of energy production (NGCC: $28,000 \times$ $10^{3}$ t C-CO $\mathrm{CO}_{2} \mathrm{eq}$ ) [Tremblay et al., 2005b] (Figure 4b).

[49] These estimated $\mathrm{C}$ emissions related to energy generation that we present here are by no means fixed or invariant. In addition to variations related to natural climate and hydrology, these net emissions are also likely to vary with the actual management and operation of the reservoir. For example, an additional power station (Eastmain-1A) is planned to go online in 2012, which will add approximately $768 \mathrm{MW}$ of capacity to the currently installed $485 \mathrm{MW}$. Assuming an equivalent operation efficiency to that of the current power house (approximately 63\%), this would generate an additional 4.2 TWh to the current $2.7 \mathrm{TWh}$, which will be fueled by the diversion of another large river (Rupert River) into the existing Eastmain-1 reservoir. Assuming that such changes in hydrological regime and in the surrounding landscape will not alter the basic $\mathrm{C}$ sink/source balance of the reservoir, this increased power generating capacity could result in long-term GHG emissions in the order of $17 \mathrm{t} \mathrm{C}$ $\mathrm{CO}_{2} \mathrm{eq} \mathrm{GWh}^{-1}$, as opposed to the $43 \mathrm{t} \mathrm{C}-\mathrm{CO}_{2} \mathrm{eq} \mathrm{GWh}^{-1}$, in the current scenario described above. This represents a very significant increase in generation efficiency of the reservoir in terms of $\mathrm{C}$ emissions, but the $\mathrm{C}$ sink/source balance of the reservoir and the affected surrounding landscape must be revisited once the water diversion has been finalized, to assess potential deviations from the basic budget proposed here.

[50] Regardless of the scenario considered, the long-term net $\mathrm{C}$ emissions from the Eastmain-1 reservoir are projected to be well below the emissions of the NGCC and all other current fossil-fuel based technologies, for similar amounts of energy produced. The results that we present here are specific for this particular flooded basin, but are likely to roughly represent reservoirs across the circumboreal region, which share many of the features of Eastmain-1 [Barros et al., 2011]; our results, however, should not be extrapolated to reservoirs in non-boreal regions. In the case of the Eastmain1 reservoir, net $\mathrm{C}$ emissions are mostly as $\mathrm{CO}_{2}$, with $\mathrm{CH}_{4}$ contributing very little, as is the case for most northern reservoirs [Tremblay et al., 2005b]. There are two main reasons for this: 1) These boreal reservoirs tend to be relatively shallow and well mixed, and also on average colder, and thus do not develop extensive or permanent bottom anoxia that could generate greater $\mathrm{CH}_{4}$ fluxes [Tremblay et al., 2005a]; 2) The boreal landscape itself has significant coverage of peatbogs and other wetlands, which naturally generate significant fluxes of $\mathrm{CH}_{4}$, so flooding may actually reduce the overall $\mathrm{CH}_{4}$ emissions from the landscape and not increase them. In contrast, in tropical and subtropical reservoirs, $\mathrm{CH}_{4}$ is proportionately much more important, because the combination of basin morphometry and climate lead to extensive anoxia and often extremely high $\mathrm{CH}_{4}$ emissions [Galy Lacaux et al., 1997; Abril et al., 2005; Tremblay et al., 2005a].

[51] We conclude that the creation of this boreal reservoir resulted in a significant shift in the $\mathrm{C}$ sink/source balance of the landscape that was flooded, with initially high net $\mathrm{C}$ emissions to the atmosphere, mostly as $\mathrm{CO}_{2}$, directly attributable to the reservoir itself. We have also shown that the effect of this reservoir is highly dynamic in time, with net reservoir emissions rapidly declining in the years following flooding, but our projections suggest that these $\mathrm{C}$ emissions will tend to stabilize at values that are nevertheless higher than those from the surrounding landscape. Calculations of $\mathrm{C}$ emissions associated with hydroelectric energy production must take these long-term dynamics into consideration. We have further shown that in this particular landscape, the integrated (terrestrial + wetland + aquatic) pre-flood net $\mathrm{C}$ exchange with the atmosphere was small, relative to the reservoir fluxes that were measured during the first four years after flooding, so subtraction of this baseline had a relatively minor influence on the apparent reservoir net fluxes. However, this may not be the case for all types of landscapes, and certainly not the case for the Eastmain-1 reservoir at longer time scales once the initial pulse subsides. For example, whereas flooding results in the loss of terrestrial primary production (therefore loss of a potential sink) and to conditions that may favor increased decomposition of soil organic $\mathrm{C}$ (therefore increase $\mathrm{C}$ flux to the atmosphere), it also impedes logging and fire, which are major structuring forces in the boreal biome [Lecomte et al., 2006], and thus lessens a major regional sink/source of atmospheric C [Amiro et al., 2009]. Long-term shifts in fire regime [Bergeron et al., 2004], and thus in the regional terrestrial and peatland $C$ exchange as well as changes in the general forest management practices could significantly shift the frame of reference and thus alter the apparent reservoir impact. The results of this project thus highlight the importance of understanding the $\mathrm{C}$ exchanges of the natural landscapes prior to flooding, and understanding the actual $\mathrm{C}$ balance and the long-term dynamics of the reservoir itself, when determining the net $\mathrm{C}$ footprint of hydroelectric reservoirs.

[52] Acknowledgments. This large and interdisciplinary research was supported by a number of sources. The aquatic portions of the project were supported by Hydro-Québec through the Eastmain-1 Research Project, by NSERC grants to YTP and PdG, and by NSERC and FQRNT Graduate scholarships to several participating students. The terrestrial aspects were supported by a grant to NTR, IBS and MG from the Canadian Foundation for Climate and Atmospheric Sciences (CFCAS RG-687). Hydro-Québec provided additional financial support for field travel and lodging as well as supplying equipment. We would like to thank all the students, research assistants and technicians at UQAM (GRIL and GEOTOP), McGill University and Environnement Illimité Inc. involved with field measurements and laboratory analyses.

\section{References}

Abril, G., F. Guerin, S. Richard, R. Delmas, C. Galy Lacaux, P. Gosse, A. Tremblay, L. Varfalvy, M. A. dos Santos, and B. Matvienko (2005), Carbon dioxide and methane emissions and the carbon budget of a 10-year old tropical reservoir (Petit Saut, French Guiana), Global Biogeochem. Cycles, 19, GB4007, doi:10.1029/2005GB002457.

Amiro, B. D., et al. (2006), Carbon, energy and water fluxes at mature and disturbed forest sites, Saskatchewan, Canada, Agric. For. Meteorol., 136, 237-251, doi:10.1016/j.agrformet.2004.1011.1012.

Amiro, B. D., A. Cantin, M. D. Flannigan, and W. J. Grot (2009), Future emission from Canadian boreal forest fire, Can. J. For. Res., 39, 383-395, doi:10.1139/X1108-1154. 
Arain, M. A., T. A. Black, A. G. Barr, P. G. Jarvis, J. M. Massheder, D. L. Verseghy, and Z. Nesic (2002), Effects of seasonal and interannual climate variability on net ecosystem productivity of boreal deciduous and conifer forests, Can. J. For. Res., 32, 878-891, doi:10.1139/x1101-1228.

Barr, A. G., T. A. Black, E. H. Hogg, N. Kljun, K. Morgenstern, and Z. Nesic (2004), Inter-annual variability in the leaf area index of a boreal aspen-hazelnut forest in relation to net ecosystem production, Agric. For. Meteorol., 126, 237-255, doi:10.1016/j.agrformet.2004.1006.1011.

Barr, A. G., T. A. Black, E. H. Hogg, T. J. Griffis, K. Morgenstern, N. Kljun, A. Theede, and Z. Nesic (2007), Climatic controls on the carbon and water balances of a boreal aspen forest, 1994-2003, Global Change Biol., 13, 561-576, doi:10.1111/j.1365-2486.2006.01220.x.

Barros, N., V. Huszar, J. J. Cole, L. J. Tranvik, D. Bastviken, P. A del Giorgio, Y. T. Prairie, and F. Roland (2011), Carbon emission from hydroelectric reservoirs linked to reservoir age and latitude, Nat. Geosci., 4, 593-596, doi:10.1038/ngeo1211.

Bastien, J., M. Demarty, and A. Tremblay (2011a), $\mathrm{CO}_{2}$ and $\mathrm{CH}_{4}$ diffusive and degassing emissions from 2003 to 2009 at Eastmain 1 hydroelectric reservoir, Québec, Canada, Inland Waters, 1(2), 113-123.

Bastien, J., M. Demarty, and A. Tremblay (2011b), Systèmes automatisés de mesure des gaz à effet de serre-Eastmain-1, Robert-Bourassa et Rivière-des-Prairies-Résultats 2010-2011, report, 42 pp., Environ. Illimité, Montreal, Que., Canada.

Bastviken, D., L. J. Tranvik, J. A. Downing, P. M. Crill, and A. Enrich-Prast (2011), Freshwater methane emissions offset the continental carbon sink, Science, 331(6013), 50, doi:10.1126/science.1196808.

Battin, T. J., S. Luyssaert, L. A. Kaplan, A. K. Aufdenkampe, A. Richter, and L. J. Tranvik, (2009), The boundless carbon cycle, Nat. Geosci., 2 , 598-600, doi:10.1038/ngeo618.

Bergeron, Y., M. Flannigan, S. Gauthier, A. Leduc, and P. Lefort (2004), Past, current and future fire frequency in the Canadian boreal forest: Implications for sustainable forest management, Ambio, 33(6), 356-360, doi:10.1579/0044-7447-1533.1576.1356.

Blais, A.-M., S. Lorrain, Y. Plourde, and L. Varfalvy (2005), Organic carbon densities of soil and vegetation of tropical, temperate and boreal forests, in Greenhouse Gas Emissions-Fluxes and Processes: Hydroelectric Reservoirs and Natural Environments, edited by A. Tremblay et al., pp. 155-185, Springer, Berlin, doi:10.1007/3-540-26643-7 6.

Bodaly, R. A., et al. (2004), Experimenting with hydroelectric reservoirs, Environ. Sci. Technol., 38(18), 347A-352A, doi:10.1021/es040614u.

Bonneville, M.-C., I. B. Strachan, E. R. Humphreys, and N. T. Roulet (2008), Net ecosystem $\mathrm{CO}_{2}$ exchange in a temperate cattail marsh in relation to biophysical properties, Agric. For. Meteorol., 148(1), 69-81, doi:10.1016/j.agrformet.2007.09.004

Brothers, S., Y. T. Prairie, and P. A. del Giorgio (2011), Benthic and pelagic sources of carbon dioxide in boreal lakes and a young reservoir (Eastmain-1) in eastern Canada, Global Biogeochem. Cycles, 25, GB1002, doi:10.1029/2011GB004074.

Brothers, S. M., P. A. del Giorgio, C. R. Teodoru, and Y. T. Prairie (2012), Landscape heterogeneity influences carbon dioxide production in a young boreal reservoir, Can. J. Fish. Aquat. Sci., 69(3), 447-456, doi:10.1139/ f2011-174

Buffam, I., M. G. Turner, A. R. Desai, P. Hanson, J. Rusak, N. R. Lottig E. H. Stanley, and S. R. Carpenter (2011), Integrating aquatic and terrestrial components to construct a complete carbon budget for a north temperate lake district, Global Change Biol., 17(2), 1193-1211, doi:10.1111/j.1365-2486.2010.02313.x.

Christensen, T. R., T. Johansson, M. Olsrud, L. Ström, A. Lindroth, M. Mastepanov, N. Malmer, T. Friborg, P. Crill, and T. V. Callaghan (2007), A catchment-scale carbon and greenhouse gas budget of a subarctic landscape, Philos. Trans. R. Soc. A, 365, 1643-1656, doi:10.1098/ rsta.2007.2035.

Cole, J. J., and Y. T. Prairie (2009), Dissolved $\mathrm{CO}_{2}$, in Encyclopedia of Inland Waters, edited by G. E. Likens, pp. 30-34, Elsevier, Oxford, U. K., doi:10.1016/B978-012370626-3.00091-0.

Demarty, M., J. Bastien, A. Tremblay, R. H. Hesslein, and R. Gill (2009) Greenhouse gas emissions from boreal reservoirs in Manitoba and Quebec, Canada, Environ. Sci. Technol., 43(23), 8905-8915, doi:10.1021/ es8035658.

Dillon, P. J., and L. A. Molot (1997), Dissolved organic and inorganic carbon mass balances in central Ontario lakes, Biogeochemistry, 36, 29-42, doi:10.1023/A:1005731828660.

dos Santos, M. A., L. P. Rosa, B. Sikar, E. Sikar, and E. O. dos Santos (2004), Gross greenhouse gas fluxes from hydro-power reservoir compared to thermo-power plants, Energy Policy, 34(4), 481-488, doi:10.1016/j.enpol.2004.1006.1015.

Downing, J. A., et al. (2006), The global abundance and size distribution of lakes, ponds, and impoundments, Limnol. Oceanogr., 51(5), 2388-2397, doi:10.4319/1o.2006.51.5.2388.
Duchemin, E., M. Lucotte, R. Canuel, and A. Chamberland (1995), Production of the greenhouse gases $\mathrm{CH}_{4}$ and $\mathrm{CO}_{2}$ by hydroelectric reservoirs of the boreal region, Global Biogeochem. Cycles, 9(4), 529-540.

Fearnside, P. M. (1996), Hydroelectric dams in Brazilian Amazonia: Response to Rosa, Schaeffer and dos Santos, Environ. Conserv., 23(2), 105-108, doi:10.1017/S0376892900038467.

Forster, P., et al. (2007), Changes in atmospheric constituents and in radiative forcing, in Climate Change 2007: The Physical Science Basis. Contribution of Working Group I to the Fourth Assessment Report of the Intergovernmental Panel on Climate Change, edited by S. Solomon et al., pp. 131-217, Cambridge Univ. Press, New York.

Friedl, G., and A. Wüest (2002), Disrupting biogeochemical cyclesConsequences of damming, Aquat. Sci., 64, 55-65, doi:10.1007/s00027002-8054-0

Galy Lacaux, C., R. Delmas, C. Jambert, J.-F. Dumestre, L. Labroue, S. Richard, and P. Gosse (1997), Gaseous emissions and oxygen consumption in hydroelectric dams: A case study in French Guyana, Global Biogeochem. Cycles, 11(4), 471-483, doi:10.1029/1097GB01625.

Giles, J. (2006), Methane quashes green credentials of hydropower, Nature, 444(7119), 524-525, doi:10.1038/444524a.

Hesslein, R. H. (2005), Using gas exchange estimates to determine net production of $\mathrm{CO}_{2}$ in reservoirs and lakes, in Greenhouse Gas EmissionsFluxes and Processes: Hydroelectric Reservoirs and Natural Environments, edited by A. Tremblay et al., pp. 563-574, Springer, Berlin, doi:10.1007/ 3-540-26643-7 23.

Hoffert, M. I., et al. (1998), Energy implications of future stabilization of atmospheric $\mathrm{CO}_{2}$ content, Nature, 395, 881-884, doi:10.1038/27638.

Houel, S., P. Louchouarn, M. Lucotte, R. Canuel, and B. Ghaleb (2006), Translocation of soil organic matter following reservoir impoundment in boreal systems: Implication for in situ productivity, Limnol. Oceanogr. 51(3), 1497-1513, doi:10.4319/10.2006.51.3.1497

Intergovernmental Panel on Climate Change (1996), Climate Change 1995 The Science of Climate Change. Contribution of Working Group I to the Second Assessment Report of the Intergovernmental Panel on Climate Change, edited by J. T. Houghton et al., 572 pp., Cambridge Univ. Press, Cambridge, U. K.

Jonsson, A., G. Algesten, A. K. Bergstrom, K. Bishop, S. Sobek, L. J. Tranvik, and M. Jansson (2007), Integrating aquatic carbon fluxes in a boreal catchment carbon budget, J. Hydrol., 334, 141-150, doi:10.1016/ j.jhydrol.2006.1010.1003.

Karlsson, J., T. R. Christensen, P. Crill, J. Förster, D. Hammarlund, M. Jackowicz-Korczynski, U. Kokfelt, C. Roehm, and P. Rosén (2010), Quantifying the relative importance of lake emissions in the carbon budget of a subarctic catchment, J. Geophys. Res., 115, G03006, doi:10.1029/2010JG001305.

Kasischke, E. S., and L. P. Bruhwiler (2002), Emissions of carbon dioxide, carbon monoxide, and methane from boreal forest fires in 1998 , J. Geophys. Res., 107, 8146, doi:10.1029/2001JD000461. [Printed 108(D1), 2003.

Koehler, A. K., K. Murphy, G. Kiely, and M. Sottocornola (2009), Seasonal variation of DOC concentration and annual loss of DOC from an Atlantic blanket bog in South Western Ireland, Biogeochemistry, 95, 231-242, doi:10.1007/s10533-10009-19333-10539.

Kortelainen, P., and H. Pajunen (2000), Carbon store in Finnish lake sediments: A preliminary estimate, Spec. Pap. Geol. Surv. Finl., 29, 83-92.

Kortelainen, P., H. Pajunen, M. Rantakari, and M. Saarnisto (2004), A large carbon pool and small sink in boreal Holocene lake sediments, Global Change Biol., 10, 1648-1653, doi:10.1111/j.1365-2486.2004.00848.x.

Lecomte, N., M. Simard, N. Fenton, and Y. Bergeron (2006), Fire severity and long-term ecosystem biomass dynamics in coniferous boreal forests of eastern Canada, Ecosystems, 9, 1215-1230, doi:10.1007/s1002110004-10168-x.

Matthews, H. D., A. J. Weaver, M. Eby, and K. J. Meissner (2003), Radiative forcing of climate by historical land cover change, Geophys. Res. Lett., 30(2), 1055, doi:10.1029/2002GL016098.

Mkhabela, M. S., et al. (2009), Comparison of carbon dynamics and water use efficiency following fire and harvesting in Canadian boreal forests, Agric. For. Meteorol., 149, 783-794, doi:10.1016/j.agrformet.2008. 1010.1025 .

Nilsson, M., J. Sagerfors, I. Buffam, H. Laudon, T. Eriksson, A. Grelle, L. Klemedtsson, P. Weslien, and A. Lindroth (2008), Contemporary carbon accumulation in a boreal oligotrophic minerogenic mire-A significant sink after accounting for all C-fluxes, Global Change Biol., 14 , 2317-2332, doi:10.1111/j.1365-2486.2008.01654.x.

Pelletier, L. (2005), Carbon dioxide and methane fluxes of three peatlands in the La Grande Rivière Watershed, James Bay lowland, Canada, Master's thesis, 104 pp., McGill Univ., Montreal, Que., Canada.

Pelletier, L., T. R. Moore, N. T. Roulet, M. Garneau, and V. Beaulieu-Audy (2007), Methane fluxes from three peatlands in the La Grande Rivière 
watershed, James Bay lowland, Canada, J. Geophys. Res., 112, G01018, doi:10.1029/2006JG000216.

Pelletier, L., M. Garneau, and A. Tremblay (2009), $\mathrm{CO}_{2}$ and $\mathrm{CH}_{4}$ ecosystems exchange from peatlands: Eastmain-1 hydroelectric project, Québec, Canada, Verh. Int. Ver. Limnol., 30(6), 862-865.

Pelletier, L., M. Garneau, and T. R. Moore (2011), Variation in $\mathrm{CO}_{2}$ exchange over three summers at microform scale in a boreal bog, Eastmain region, Québec, Canada, J. Geophys. Res., 116, G03019, doi:10.1029/2011JG001657.

Roehm, C., and A. Tremblay (2006), The role of turbines in the GHG budget of two boreal reservoirs, Quebec, Canada, J. Geophys. Res. 111, D24101, doi:10.1029/2006JD007292.

Roehm, C., Y. T. Prairie, and P. A. del Giorgio (2009), The $p \mathrm{CO}_{2}$ dynamics in lakes in the boreal region of northern Québec, Canada, Global Biogeochem. Cycles, 23, GB3013, doi:10.1029/2008GB003297.

Rosa, L. P., and R. Schaeffer (1994), Greenhouse gas emissions from hydroelectric reservoirs, Ambio, 22, 164-165.

Rosa, L. P., and R. Schaeffer (1995), Global warming potentials: The case of emissions from dams, Energy Policy, 23, 149-158, doi:10.1016/03014215(1095)91418-C.

Rosenberg, D. M., R. A. Bodaly, and P. J. Usher (1995), Environmental and social impacts of large scale hydroelectric development: Who is listening? Global Environ. Change, 5(2), 127-148, doi:10.1016/0959-3780(1095) 00018-J.

Rosenberg, D. M., F. Berkes, R. A. Bodaly, R. E. Hecky, C. A. Kelly, and J. W. M. Rudd (1997), Large-scale impacts of hydroelectric development, Environ. Rev., 5(1), 27-54, doi:10.1139/a97-001.

Roulet, N. T., P. M. Lafleur, P. J. H. Richard, T. R. Moore, E. R. Humphreys, and J. L. Bubier (2007), Contemporary carbon balance and late Holocene carbon accumulation in a northern peatland, Global Change Biol., 13, 379-411, doi:10.1111/j.1365-2486.2006.01292.x.

Spath, P. L., and M. K. Mann (2000), Life-cycle assessment of a natural gas combine-cycle power generation system, Rep. NREL/TP 570-27715, Natl. Renewable Energy Lab., Golden, Colo., doi:10.2172/776930.

St. Louis, V. L., C. A. Kelly, E. Duchemin, J. W. M. Rudd, and D. M Rosenberg (2000), Reservoir surfaces as sources of greenhouse gases to the atmosphere: A global estimate, BioScience, 50, 766-775, doi:10.1641/ 0006-3568(2000)050[0766:RSASOG]2.0.CO;2.

Teodoru, C. R., P. A. del Giorgio, Y. T. Prairie, and M. Camire (2009), $p \mathrm{CO}_{2}$ dynamics in boreal streams of northern Québec, Canada, Global Biogeochem. Cycles, 23, GB2012, doi:10.1029/2008GB003404.
Teodoru, C. R., Y. T. Prairie, and P. A. del Giorgio (2011), Spatial heterogeneity of surface $\mathrm{CO}_{2}$ fluxes in a newly created Eastmain-1 reservoir in northern Québec, Canada, Ecosystems, 14(1), 28-46, doi:10.1007/ s10021-010-9393-7.

Tranvik, L. J., et al. (2009), Lakes and reservoirs as regulators of carbon cycling and climate, Limnol. Oceanogr., 54(6), 2298-2314, doi:10.4319/ lo.2009.54.6 part 2.2298.

Tremblay, A., J. Therrien, B. Hamlin, E. Wichmann, and L. J. LeDrew (2005a), GHG emissions from boreal reservoirs and natural aquatic ecosystems, in Greenhouse Gas Emissions-Fluxes and Processes: Hydroelectric Reservoirs and Natural Environments, edited by A. Tremblay et al., pp. 209-232, Springer, Berlin, doi:10.1007/3-540-26643-7 8

Tremblay, A., L. Varfalvy, C. Roehm, and M. Garneau (2005b), Synthesis, in Greenhouse Gas Emissions-Fluxes and Processes: Hydroelectric Reservoirs and Natural Environments, edited by A. Tremblay et al., pp. 637-659, Springer, Berlin, doi:10.1007/3-540-26643-7 26.

Vachon, D., Y. T. Prairie, and J. J. Cole (2010), The relationship between near-surface turbulence and gas transfer velocity in freshwater systems and its implications for floating chamber measurements of gas exchange, Limnol. Oceanogr., 55(4), 1723-1732, doi:10.4319/lo.2010.1755.1724. 1723.

Victor, D. G. (1998), Strategies for cutting carbon, Nature, 395, 837-838, doi: $10.1038 / 27532$

von Wachenfeldt, E., and L. J. Tranvik (2008), Sedimentation in borea lakes-The role of flocculation of allochthonous dissolved organic matter in water column, Ecosystems, 11, 803-814, doi:10.1007/s10021-1000819162-z.

Vörösmarty, C. J., K. Sharma, B. Fekete, A. H. Copeland, J. Holden, J. Marble, and J. A. Lough (1997), The storage and aging of continental runoff in large reservoir systems of the world, Ambio, 26, 210-219.

World Commission on Dams (2000), Dams and Development: A New Framework for Decision-Making, Earthscan, London.

Yuan, F., M. A. Arain, A. G. Barr, T. A. Black, C. P. A. Bourque, C. Coursolle, H. A. Margolis, J. H. McCaughey, and S. C. Wofsy (2008), Modeling analysis of primary controls on net ecosystem productivity of seven boreal and temperate coniferous forests across a continental transect, Global Change Biol., 14(8), 1765-1784, doi:10.1111/ j.1365-2486.2008.01612.x. 